NBER WORKING PAPER SERIES

\title{
UNDERSTANDING HETEROGENEITY IN THE EFFECTS OF BIRTH WEIGHT ON ADULT COGNITION AND WAGES
}

\author{
C. Justin Cook \\ Jason M. Fletcher \\ Working Paper 20895 \\ http://www.nber.org/papers/w20895 \\ NATIONAL BUREAU OF ECONOMIC RESEARCH \\ 1050 Massachusetts Avenue \\ Cambridge, MA 02138 \\ January 2015
}

The authors acknowledge co-funding from the National Institute of Child Health and Human Development and the Office of Behavioral and Social Sciences Research (OBSSR) (1R21HD071884). This research uses data from the Wisconsin Longitudinal Study (WLS) of the University of Wisconsin-Madison. Since 1991, the WLS has been supported principally by the National Institute on Aging (AG-9775 AG-21079 and AG-033285), with additional support from the Vilas Estate Trust, the National Science Foundation, the Spencer Foundation, and the Graduate School of the University of Wisconsin-Madison. Since 1992, data have been collected by the University of Wisconsin Survey Center. A public use file of data from the Wisconsin Longitudinal Study is available from the Wisconsin Longitudinal Study, University of Wisconsin-Madison, 1180 Observatory Drive, Madison, Wisconsin 53706 and at http://www.ssc.wisc.edu/wlsresearch/data/. The opinions expressed herein are those of the authors. The authors thank Jason Boardman, Dalton Conley, Costas Meghir, and seminar participants at the Yale Health Economics Workshop, the Institute for Research on Poverty at the University of Wisconsin, the Department of Health Studies at the University of Chicago, the Neuroscience and Public Policy program at the University of Wisconsin for helpful suggestions. The views expressed herein are those of the authors and do not necessarily reflect the views of the National Bureau of Economic Research.

NBER working papers are circulated for discussion and comment purposes. They have not been peerreviewed or been subject to the review by the NBER Board of Directors that accompanies official NBER publications.

(C) 2015 by C. Justin Cook and Jason M. Fletcher. All rights reserved. Short sections of text, not to exceed two paragraphs, may be quoted without explicit permission provided that full credit, including (c) notice, is given to the source. 
Understanding Heterogeneity in the Effects of Birth Weight on Adult Cognition and Wages C. Justin Cook and Jason M. Fletcher

NBER Working Paper No. 20895

January 2015

JEL No. I1,J1,J24

\begin{abstract}
$\underline{\text { ABSTRACT }}$
A large economics literature has shown long term impacts of birth weight on adult outcomes, including IQ and earnings that are often robust to sibling or twin fixed effects. We examine potential mechanisms underlying these effects by incorporating findings from the genetics and neuroscience literatures. We use a sample of siblings combined with an "orchids and dandelions hypothesis", where the IQ of genetic dandelions is not affected by in utero nutrition variation but genetic orchids thrive under advantageous conditions and wilt in poor conditions. Indeed, using variation in three candidate genes related to neuroplasticity (APOE, BDNF, and COMT), we find substantial heterogeneity in the associations between birth weight and adult outcomes, where part of the population (i.e., "dandelions") is not affected by birth weight variation. Our results help uncover why birth weight affects adult outcomes.
\end{abstract}

C. Justin Cook

School of Social Sciences, Humanities and Arts

University of California, Merced

jcook9@ucmerced.edu

Jason M. Fletcher

University of Wisconsin-Madison

La Follette School of Public Affairs

1225 Observatory Drive

Madison, WI 53706

and NBER

jfletcher@lafollette.wisc.edu 


\section{Introduction}

A large literature in economics and other disciplines has established the importance of early nutrition environments, which is often measured by birth weight, on both short and long term outcomes. Short term impacts are most straightforward to motivate, where babies born with low birth weight, from having lower levels of intrauterine nutrition or are otherwise unhealthy, have been shown to have higher infant mortality and have higher medical care costs (Almond, Chay and Lee 2005). The existence and magnitude of longer term (i.e., adult) impacts are less obvious but have been the subject of a growing body of work. ${ }^{2}$ One motivation for this line of research is the fetal origins hypothesis by Barker (1995) who provides evidence that individuals born with low birth weight are prone to heart disease and type 2 diabetes later in life. In economics, Black et al. (2007) further test and extend this hypothesis by showing that birth weight differences between twins have lifelong impacts on IQ, labor force participation, and earnings. These findings are further supported by a number of natural experiments. A long term follow up of individuals who were in utero during the Dutch Hunger Winter (Stein et al. 1975), in which fetuses were exogenously exposed to poor intrauterine nutrition during the famine of 1944-45, have been shown to have later experienced a range of negative health and economic outcomes (Stein et al. 2005, de Roij et al. 2010, Schultz et al. 2012). Additionally, individuals in utero during the month of Ramadan, which is associated with diurnal fasting, are shown to have reduced birth weights, leading to reduced mental performance later in life (Almond and Mazumder 2011).

The biological mechanisms linking poor nutrition in utero and long term effects on cognition are not fully developed, but several hypotheses have been proposed. A tenant of the fetal origins hypothesis is that nutritional insults cause the body to shift resources to the brain, leaving other organ systems prone to future deficits from this critical period of under-development. Heterogeneity in the ability to shift resources as well as differences in the potential plasticity in neurodevelopment suggests

\footnotetext{
${ }^{2}$ See Figlio et al. (2013) and Fletcher (2011) for evidence of "medium run" impacts of birth weight between ages 5 and 18. For "longer run" impacts see Conley and Bennett 2000, Conley et al. 2003, and Hack et al. 2002.
} 
there could be varying impacts on cognition as well as health across individuals born with low birth weight.

Even with these hypothesized resource shifts to protect the brain, there is also ample evidence of long term effects on cognition. Most related to the current work is the evidence of effects of early nutrition on cognitive development, particularly IQ in early adulthood. ${ }^{3}$ A positive and statistically significant association between birth weight and IQ has been found in a number of studies and samples (see e.g., Black et al. 2007; Newcombe et al. 2007). For example Newcombe et al. (2007) finds that a kilogram increase in birth weight is associated with a 3 point increase in IQ. Furthermore, this link between birth weight and IQ is found within MZ twin pairs, decreasing the likelihood of spurious results from unmeasured family background or genetics. This has important economic consequences, as IQ has both direct and indirect impacts on lifetime earnings, schooling decisions, and criminal and risky behavior (Heckman et al. 2006, Gensowski 2013). However, there is currently limited understanding of the mechanisms linking low birth weight with adult IQ and labor market outcomes. Physiologically, emerging evidence suggests that birth weight has a positive, linear association with regional surface area and total volume of the brain (Walhovd et al. 2012). Additional research to further uncover mechanisms could allow us to gain a better understanding of the determinants of adult IQ and productivity as well as, more speculatively, to suggest avenues to target resources at individuals most likely to be affected by low birth weight.

Furthermore, this link between birth weight and IQ is found within $M Z$ twin pairs, decreasing the likelihood of spurious results from unmeasured family background or genetics. This has important economic consequences, as IQ has both direct and indirect impacts on lifetime earnings, schooling decisions, and criminal and risky behavior (Heckman et al. 2006, Gensowski 2013). However, there is

\footnotetext{
${ }^{3}$ While differential birth weight does provide a head-start or lag in cognitive development, post-natal family and schooling environments are also associated with later life cognitive development (Barnett et al. 2007, Cunha et al. 2006).
} 
currently limited understanding of the mechanisms linking low birth weight with adult IQ and labor market outcomes. Physiologically, emerging evidence suggests that birth weight has a positive, linear association with regional surface area and total volume of the brain (Walhovd et al. 2012). Additional research to further uncover mechanisms could allow us to gain a better understanding of the determinants of adult IQ and productivity as well as, more speculatively, to suggest avenues to target resources at individuals most likely to be affected by low birth weight.

The main idea of the current work is to explore whether genetic variation related to neuroplasticity may be essential sources of heterogeneity in the impacts of low birth weight on adult outcomes. The framework follows that proposed by previous studies examining the moderating properties of particular genetic variants within varied environments. ${ }^{4}$ The idea being that certain genetic variants moderate, or amplify, the effects of exposure to a treatment-and this variation in impact may then help us understand mechanisms linking low birth weight with adult outcomes.

In short, our main hypothesis is that candidate genetic variants, which have a previously shown relationship with an ability of the brain to strengthen or rewire neural connections, what we refer to broadly as neuroplasticity, moderate the negative association between low birth weight and later life cognitive performance. ${ }^{5}$ With this understanding, we estimate a within-family multiplicative interaction between birth weight and a candidate gene neuroplasticity risk score. To preview our findings, birth weight is shown to have a strong positive association with later-life IQ only for individuals endowed with few neuroplastic variants, whereas the most plastic individuals have no statistically significant association between birth weight and IQ. Furthermore, we are able to control for common environmental conditions amongst siblings, allowing us to account for shared harmful or beneficial post-

\footnotetext{
${ }^{4}$ One of the first, and most famous, papers on gene-environment interactions is by Caspi et al. (2003), in which the authors show that childhood abuse leads to more severe later-life depression for individuals containing a gene variant, or allele, for the serotonin transporter gene 5-HTT. For review, please see Rutter et al. (2005) and Caspi and Moffitt (2006). Additional studies that are similar in spirit and design include Shanahan et al. (2008) and Thompson (2014).

${ }^{5}$ Neuroplasticity is discussed in detail in the Section 1.1.
} 
natal environments that may also influence IQ. The leveraging of the within-sibling genome also allows a quasi-experiment in genetics, as genetic variation between full biological siblings is random and has been labeled as a "genetic lottery" in prior work (Fletcher and Lehrer 2009, 2011).

\subsection{Neuroplasticity}

Neuroplasticity refers to the ability of the brain to maintain and strengthen neural connections as well as developing new connections between neurons (Pascual-Leon et al. 2005). ${ }^{6}$ It is a constant process of strengthening and replacing neural connections, affecting the structure and function of axons, dendrites, and synapses (Teter and Ashford 2002). Plasticity is commonly invoked after brain injuries, or insults, such as a stroke; after which, neural networks are re-organized from damaged to undamaged areas within the brain (Frost et al. 2003, Pascual-Leon et al. 2005). Other examples of neuroplasticity are found in the increased sensitivity in touching and hearing in the blind. For our purposes, plasticity represents an ability to respond to environmental shocks-i.e., poor early life nutrition. Individuals with greater plasticity, or individuals who are more able to recover from negative cognitive shocks, should be cognitively robust to a poor in utero environment. In other words, birth weight may not be a major predictor of cognitive development, or earnings, for individuals with greater neuroplasticity.

In order to measure neuroplasticity, we will use the variation in genetic markers. The genes under consideration are $A P O E, C O M T$, and $B D N F$. All three genes are associated with neuroplasticity, both directly and in relation to one another. ${ }^{7}$ The three genes were selected because they are the only ones available in the WLS dataset that have been shown to be related to neuroplasticity in the literature, as we document below. ${ }^{8}$ Focusing only on these three genes allows us to reduce to concern

\footnotetext{
${ }^{6}$ Neuroplasticity is not solely a positive, or favorable, condition. Continual remapping may lead to degenerative conditions (Pascual-Leon 2005, Teter and Ashford 2002).

${ }^{7}$ All genetic variants under consideration are single-nucleotide polymorphisms (SNP). A SNP is a single change along a sequence of DNA. For example, "ATA" versus "ATC", where the " $A$ " and " $C$ " are variants for the third nucleic base in the sequence. Each SNP under consideration is assigned a reference, or " $r s$," number. ${ }^{8}$ See complete list of SNPs at http://www.ssc.wisc.edu/wlsresearch/documentation/supdoc/biomarker/cor1019b SNPs in wave1 data.pdf
} 
of multiple hypothesis testing. ${ }^{9}$ We also show below that the results are robust to a number of different ways of measuring neuroplasticity based on these three genes.

$A P O E$ (apolipoprotein $\mathrm{E}$ ) is associated with the transportation of lipids, or fatty acids, within the brain. The gene variant under consideration for the current work is the E4 variant, which has strong associations with Alzheimer's disease. ${ }^{10}$ APOE4 is particularly poor at removing plaques within neural pathways, resulting in poor synaptic plasticity (Tromer et al. 2005); therefore, the E4 variant has a negative association with neuroplasticity. ${ }^{11}$ When constructing our measure for neuroplasticity, we consider individuals who do not have the E4 variant for the APOE gene.

The Val66Met locus (rs6265) of the BDNF (brain-derived neutrophic factor) gene has been shown to be related to neuroplasticity. ${ }^{12} B D N F$ is a protein associated with nerve growth, which is influenced by both the genotype as well as by early life stress (Roceri et al. 2002, Duman and Monteggia 2006). The presence of this protein is positively associated with hippocampal plasticity and development (Mizuno et al. 2000, Witte et al. 2012). Therefore, the genetic variant associated with greater production of this protein, and greater robustness to early stress - the Val, or " $A$ " variant of SNP rs6265-is considered for our measure of neuroplasticity.

The COMT gene is associated with the production of the catechol-O-methyl transferase protein, an enzyme that breaks down catecholamines--e.g., dopamine. The Met variant of the Val158Met locus ( $r$ 4680) is associated with reduced production of COMT and a higher corresponding level of dopamine in the prefrontal cortex. This particular variant of the COMT gene has a debatable, direct impact on

\footnotetext{
${ }^{9}$ For example, the Health and Retirement Study has recently released over 2 million genetic variants for each of the over 12,000 respondents in the genetic sample. This would allow a nearly infinite number of ways to characterize neuroplasticity, and similarly allow a very large number of regressions to be examined, leading to multiple-comparison concerns.

${ }^{10}$ The four variants of the APOE gene are determined by two SNPs: rs429358 and rs7412. The E4 variant is defined as having a "C" variant for each.

${ }^{11}$ The negative association between the E4 variant and plasticity may be one reason for its correlation with Alzheimer's disease (Teter and Ashford 2002).

${ }^{12}$ For review, please see Cheeran et al. (2009).
} 
memory. ${ }^{13}$ For our purposes, the Met variant of the COMT gene, and the corresponding increase in prefrontal dopamine, is theorized to interact with $B D N F$ by increasing long-term potentiation, a key determinant of neuroplasticity. ${ }^{14}$ This is confirmed in Witte et al. (2012), who find the Met variant of the rs4680 SNP in COMT has an interactive effect with the Val variant of the rs6265 SNP in the BDNF gene in increasing neuroplasticity.

Our baseline measure for neuroplasticity is the sum of the number of favorable variants for each neuroplasticity gene mentioned above, where every individual has two copies for each gene-one from the mother and one from the father. For $A P O E$, the favorable variant is simply not having the E4 variant; for $B D N F$, the Val allele is favorable for neuroplasticity; and for COMT, the Met allele is favorable. Therefore, each individual has 0,1 , or 2 favorable variants, and the additive score of the three neuroplasticity genes takes a value between 0 and 6 (see Figure 2 below for the distribution in our sample). The additive neuroplasticity score is similar to recently used genetic risk scores (see e.g., Belsky et al. 2012, Plomin et al. 2009); however, a key difference is that the SNPs used in the construction of the neuroplasticity "risk" score are not from a genome wide association study, but are candidate genes that have a previously shown relationship with neuroplasticity. As a check to this specification, we also explore the multiplicative interaction for the total number of favorable variants as well as an indicator for individuals who have at least one copy of each favorable gene variant. ${ }^{15}$ Appendix B also shows results for each gene in isolation.

In summary, neuroplasticity represents the ability of an individual to respond to cognitively damaging environments-i.e., poor in utero nutrition. To measure neuroplasticity, we explore three genes that have a biological association with neuroplasticity. We hypothesize that the neuroplasticity

\footnotetext{
${ }^{13}$ For review, please see Witte and Floel (2011).

${ }^{14}$ Long-term potentiation is the strengthening of neural pathways by a persistent increase in signal between two neurons (Bliss and Collinridge 1993).

${ }^{15}$ The interaction between the individual neuroplasticity genes is intended to capture the previously found interaction between BDNF and COMT, as well as the strong negative effects associated with the E4 variant of APOE.
} 
genes under consideration moderate the effect of birth weight, or early nutrition, on cognition and adult wages.

\subsection{Differential Susceptibility}

A recent line of research in biology, genetics, and evolution, among other disciplines has started to attempt explanations for the evolution of favorable and unfavorable traits within specific environments. A first focus was the Stress-Diathesis hypothesis, which suggested that "risky" genotypes would face severe consequences when placed in "risky environments" (e.g. Caspi et al. 2003). An open question for this hypothesis is why natural selection would favor genotypes that are "risky" with no compensating benefit to the organism. In in response to this issue, the Differential Susceptibility hypothesis has emerged, which is more commonly known as "orchids and dandelions" (Belsky 2005). It argues that some individuals are robust to environmental exposure, both positive and negative (i.e., dandelions). Other individuals, however, are sensitive to the environment in which they are placed (i.e., orchids). At the level of a species, it would be advantageous to have both "types" of individuals - those who are relatively insensitive to modest changes in the environment, and those who could survive (and thrive) given large unforeseen changes in the environment.

For our purposes, neuroplasticity can be seen as a mechanism for environmental robustness. Our main argument is that the in utero environment is unlikely to affect individuals with greater neuroplasticity. These plastic individuals are dandelions while those without genetic variants that promote plasticity are orchids.

\section{Data and Empirical Methodology}

\subsection{Data}

The data come from the Wisconsin Longitudinal Study (WLS). The WLS is a random sample composed of one-third of 1957 high school graduates. Additional data has been collected from a selected sibling and from spouses of the graduates. Of importance to the current work is data on both the graduates and 
their selected siblings, for which data were collected in 1957, 1964, 1975, 1992, and 2003 and 1977, 1993, and 2004, respectively.

Our base sample consists of 469 sibling pairs (938 individuals). As will be explained shortly, the sibling sample is needed to control for both unobserved genes and environments, which may lead to spurious estimates. The WLS contains data on IQ, our primary dependent variable of interest, for roughly 17,000 individuals: 11,000 graduates and 6,000 selected siblings. ${ }^{16}$ A large portion of this available data is unused, however, due to the availability of birth weight and DNA data, which were collected in 2003 (2004), a time when the graduates and siblings were roughly 60 years of age. The sample of individuals who report both birth weight and DNA data is less than one-third of our 17,000 sample, from which data are used for roughly 3,800 individuals: 2,600 graduates and 1,200 siblings. Furthermore, data for complete sibling pairs reduces the sample of individuals with DNA and birth weight data from 3,800 to 938 . This reduced sample constitutes our base sample and is composed of sibling pairs with complete data on DNA, birth weight, $I Q$, and other covariates used in estimation.

Due to the birth weight and DNA data being collected at such a late period, sample selection is a concern. ${ }^{17}$ It is likely that surviving until the 2003 (2004) wave is correlated with IQ and other economic and health measures. Therefore, we construct an attrition weight by first regressing an indicator for being in the sibling-pair sample on IQ, birth year, sex, and a sibling indicator. ${ }^{18}$ Next, the inverse of this

\footnotetext{
${ }^{16}$ These data are truncated slightly by the availability of other covariates used within the paper. The appendix contains summary statistics for a large number of possible samples.

${ }^{17}$ A further concern is in the retrospective collection of birth weight in 2003, a time in which the participants are in their mid-60s. While we cannot rule out error, we have no reason to believe that any error in self-reported birth weight is non-random. For example, Jaworowicz et al. (2010) find no evidence of demographic differences in birth weight errors, implying the errors are potentially random and can be used for unbiased estimation. Furthermore as shown in previous studies, the amount of error in retrospective reports of birth weight is generally small. For example, O'Sullivan, Mark, and Louise (2000) find more than $75 \%$ of parental reports are within $50 \mathrm{~g}$ of that recorded in hospital records and found no difference in reporting errors by socioeconomic status. Yaw, Vera, and Steven (1998) find a median misreport of birth weight of $10 \mathrm{~g}$ between mother and hospital records. Hewson and Bennett (1987) also note that hospital records are not always error-free. Jaworowicz et al. (2010) find self-reported measures of birth weight are highly correlated with hospital records, with $67 \%$ being identical. ${ }^{18}$ Siblings have greater variation in age, as well as compromising a greater proportion of individuals with birth weight and DNA data.
} 
probability is used as an attrition weight in estimation, potentially correcting for issues associated with sample selection. Comparing summary statistics across sample specifications in the appendix, the sample weights appear to correct for the differences in IQ, as well as other variables. Indeed, the (weighted) summary statistics for the analysis sample is nearly identical to the full sample of 17,000 individuals (see Table A1). ${ }^{19}$

Our primary dependent variable throughout the paper is $I Q$, which is mapped from HenmonNelson test scores and is representative of IQ for high school juniors. As an additional dependent variable, we also use the hourly wage rate in 1992 (1993). This variable is intended to capture economic productivity differences. The data from 1992 (1993) represent a period in which most of our sample is working (i.e, graduates are roughly 53 years of age) and has the greatest amount of coverage across waves.

As described in Section 1.1, our main independent variable of interest is neuroplasticity, which is measured in several ways, including by the interaction between 3 genes associated with neuroplasticity. These 3 genes are $A P O E, B D N F$, and COMT. The plastic allele of $A P O E$ is defined as not being the E4 variant. The E4 variant is represented by having a " $\mathrm{C}$ " variant at both SNP rs429358 and SNP rs7412. ${ }^{20}$ The plastic variant is coded as 2 if an individual has no copies of the E4 variant, as 1 if the individual contains one copy of the E4 variant, and 0 for two copies. ${ }^{21}$ For BDNF, the Val variant is seen as plastic. This is defined as having a " $G$ " variant at SNP rs6265, where having two " $G$ " variants is coded as 2, one

\footnotetext{
${ }^{19}$ The Vital Statistics of 1950 provide the first national data on birth weight. Using this data as a proxy for a nationally representative birth weight cohort, we are able to assess the validity of the birth weight statistics for our base sibling sample, the majority of which were born in 1940. For 1950, the average birth weight in the U.S. is 3,310 grams, which is comparable with 3,367 grams, the average birth weight of our sibling sample. For whites in 1950 , which is more representative of our base sibling sample, the average birth weight is 3,320 grams. Furthermore, $7.6 \%$ of births are less than 2,500 grams in 1950 compared to roughly $8 \%$ for our sibling sample. ${ }^{20}$ In our base sibling sample, the frequencies of the "C" variant for SNP rs429358 and rs 7412 are $14.9 \%$ and $92 \%$, respectively; this is comparable to frequencies in the 1000 Genomes project, which give frequencies in European populations of $14 \%$ and $93 \%$ (McVean et al. 2012).

${ }^{21}$ Every individual has two copies of each gene: one from the mother and one from the father.
} 
" $G$ " variant is coded as 1 , and having no " $G$ " variants is coded as $0 .{ }^{22}$ For COMT, the Met variant is associated with neuroplasticity. The " $A$ " variant of SNP rs4680 is associated with lower enzymatic activity and increased plasticity. The " $\mathrm{A}$ " variant for this SNP of COMT is coded in an identical manner to the "G" variant of SNP rs6265 for BDNF. ${ }^{23}$

Our main measure of neuroplasticity is the additive score across these three genes (i.e., APOE+ $B D N F+C O M T)$, giving a minimum of 0 and maximum of $6 .{ }^{24}$ The sum is used to measure neuroplasticity because each of the three genetic variants has been shown to have an effect on plasticity, both separately in conjunction: BDNF and COMT have a previously documented interaction in plasticity, whereas the E4 variant of APOE is highly damaging to plasticity (Trommer et al. 2005, Witte et al. 2012). For our base sibling sample, individuals contain on average 4.35 plastic alleles. For robustness, we will also use the multiplicative interaction of plastic alleles and an indicator for possessing at least one plastic variant at each locus as well as examine effects for each single gene in Appendix B. Other covariates include sex, birth order, birth year, a sibling indicator, mother's education, father's education, and a score for socio-economic status, though several of the measures (as well as all shared family characteristics) will be subsumed in our preferred family fixed effects specification.

An additional issue in the use of our sample (and the WLS more broadly) is the lack of ethnic diversity. Our base sibling sample is composed entirely of peoples of European descent. ${ }^{25}$ This implies that any findings may not be generalizable to a larger, more ethnically diverse population such as the

\footnotetext{
${ }^{22}$ In comparison to frequencies in the 1000 Genomes Project, our base sample frequency of the Val variant is 80.5\%, whereas the European frequency in 1000 Genomes is $80 \%$ (McVean et al. 2012).

${ }^{23}$ In our base sibling sample, the frequency of the Met variant of rs4680 is $51.1 \%$. This is roughly identical to the $52 \%$ frequency within European populations (McVean et al. 2012).

${ }^{24}$ Section B within the Supplemental Appendix analyzes the associations of each plastic gene separately as well as each 2-way additive score. Results, while not always statistically significant, are similar in sign and magnitude.

${ }^{25}$ Less than $1 \%$ of the WLS is composed of non-white ethnicities.
} 
United States. The ethnic homogeneity, however, is beneficial in our study of genes and environments. Our results are unlikely to be biased by genetic, or environmental, clustering across ethnicities. ${ }^{26}$

\subsection{Empirical Methodology}

Our main empirical strategy considers the interaction between our genetic measure of neuroplasticity and exposure in early childhood, or in utero, to poor nutrition, for which birth weight is used as a proxy. Our main estimating equation is given by the following form:

$$
\mathrm{IQ}_{i j}=\beta_{0}+\beta_{1} N P_{i j}+\beta_{2} B W_{i j}+\beta_{3} N P_{i j} \times B W_{i j}+\boldsymbol{\beta}_{\mathbf{4}}^{\prime} \boldsymbol{X}_{i j}+\boldsymbol{\beta}_{\mathbf{5}}^{\prime} \boldsymbol{Z}_{\boldsymbol{j}}+\gamma I_{j}+\varepsilon_{i j}
$$

where we consider $i$ individuals within $j$ families. Our main outcome of interest is IQ, and the coefficient of interest is $\beta_{3}$, which measures the association of the interaction between birth weight and neuroplasticity. Our hypothesis being that $\beta_{3}$ is negative and significant, while the main effect of birth weight, measured by $\beta_{2}$, is positive and significant. This finding would be consistent with the hypothesis that the early nutrition environment does play a role in cognitive development, but that this effect is reduced in "plastic" individuals. All estimations also include individual and family level controlsrepresented by $\boldsymbol{X}_{i j}$ and $\boldsymbol{Z}_{j}$, respectively - that include family SES and education, individual demographic characteristics, as well as within family dynamics, such as birth order, that have effects on learning and cognition (Black et al. 2005).

In addition to individual and family level controls, our extended estimating equation includes family, or sibling, fixed effects. ${ }^{27}$ As argued in Fletcher and Lehrer (2011), Conley and Rauscher (2012), and Cook and Fletcher (2013), the inclusion of sibling fixed effects control for both unobserved genetic and environmental influences, which may bias estimation. Since siblings share approximately $50 \%$ of unique genetic variation, sibling fixed effects partially (i.e., 50\%) control for unobserved genetic influences that may bias the gene-environment interaction by accounting for a latent gene-gene

\footnotetext{
${ }^{26}$ Within family estimation should also eliminate bias associated with population stratification.

${ }^{27}$ In the sibling fixed effects specification, shared family-level controls are excluded.
} 
interaction. ${ }^{28}$ In addition to controlling for potentially unobserved gene-gene interactions, the use of sibling fixed effects also allows us to control, in part, for heritable IQ shared between siblings (Black et al. 2009). The use of sibling fixed effects also allows the genetic variation in our sample to be considered quasi-exogenous, as differences in genotype of full biological siblings is the outcome of a "genetic lottery" (Fletcher and Lehrer 2009, 2011).

While controlling for unobserved genetic variation is important in verifying the effect of the GE interaction, it is also important to control for unobserved environmental differences across families. Birth weight is plausibly exogenous between siblings, but may be associated with income or education across families. We are able to control for parental income and education; however, there are many unobservables across families (e.g., parental attention, post-natal nutrition, childhood activities, quality of education, etc.) that are associated with cognitive development and high school IQ. Furthermore, across family variation is strongly associated with cognitive development (Carneiro and Heckman 2003, Cunha et al. 2006, Heckman and Masterov 2004). Therefore, we use within family specification for our preferred results. ${ }^{29}$

However, the use of within-family estimation does not eliminate the potential for bias arising across time. We are unable to account for across time differences that may be associated with both birth weight and later-life outcomes-e.g., differences in gestation or mother's nutrition, income, and smoking behavior between siblings' birth. ${ }^{30}$ In other words, we are unable to account for insults that potentially have independent associations with fetal development, measured by birth weight, and laterlife outcomes. Through exploiting a number of natural experiments and by focusing the analysis on

\footnotetext{
${ }^{28}$ Indeed, the principle of the independent assortment of genes across the genome (especially genes not in close proximity) suggests a limited role for gene-gene interactions as a possible alternative-hypothesis for our results. ${ }^{29}$ Descriptive statistics for our sibling sample based on discordant/concordant siblings are included in Section A of the Supplemental Appendix.

${ }^{30}$ A partial control for the differential timing of births is found from the inclusion of birth year in our baseline set of controls. Assuming incomes rise throughout the life-course, later birth years correspond to improved parental income; however, birth year is unable to capture income shocks.
} 
twins, who are born at the same, a large number of studies have indeed found an effect of birth weight on later life cognition. ${ }^{31}$ For the current study, however, the exogeneity of birth weight cannot be established. Therefore, our proposed relationship between birth weight and cognition in high school may be the product of an unobserved time difference across siblings' births, and any results found using this relationship should not be interpreted as causative. ${ }^{32}$ In addition to the exogeneity concerns of our environmental difference of interest, birth weight, we are unable to fully account for the mechanism in which our genetic variants of interest are associated with IQ. While we will show that no statistically significant association exists between either neuroplastic variant or combinations thereof, we cannot rule out that these genetic variants influence IQ through additional channels. ${ }^{33}$ Given the endogeneity concerns of both our environmental and genetic variables of interest, we view our results showing evidence of genetic moderation in the associations between birth weight and IQ to be suggestive but not conclusive.

All tables are organized as following: column (1) presents OLS estimates of the estimating equation above, excluding sibling fixed effects; column (2) weights the estimation of column (1) by the inverse of the probability of being in our base sibling-pair sample; and column (3) performs within family estimation, excluding family-level controls.

\footnotetext{
${ }^{31}$ See Almond and Currie (2011) for comprehensive review.

${ }^{32} \mathrm{~A}$ further complicating factor is tied to parental investments, from which the poor nutritional status of low birth weight individuals is lessened/reinforced from increased/decreased parental investment, leading to a convergence/further divergence in outcomes between siblings (Datar, Kilburn, and Loughran 2010). For our analysis, this potential complication is alleviated due to the random assignment of our genetic endowment of interest. While low birth weight individuals may receive less or more parental investments, we have no reason to suspect that this investment is correlated with the unobserved and randomly determined genetic endowment of each sibling.

${ }^{33}$ Of particular concern is the possibility of a gene-environment correlation, or rGE. Passive rGE implies a genetic variant is associated with an expressed trait in the parent that influences early life outcomes or birth weight. This genetic variant is then passed to the offspring; however, given that our preferred specification controls for unobserved characteristics shared between siblings, this mechanism is not a major concern. Evocative rGE implies that the offspring's genotype affects the in utero environment in some way that would produce changes in birth weight and IQ.
} 


\section{Results}

\subsection{Baseline}

Associations between neuroplasticity, measured by the interaction of corresponding gene variants, and birth weight on high school IQ are examined in Table 1. All columns in Table 1 include all relevant individual and family level controls, which include birth order, birth year, a sibling indicator, sex, mother's education, father's education, and family-level SES in 1957 with standard errors clustered at the family level. The OLS estimation of column (1) shows that while birth weight does have a positive and significant association with later-life IQ, our genetic measure for neuroplasticity does not have a statistically significant relationship with IQ. This is to be expected; our hypothesis is that neuroplasticity is associated with correcting cognitively harmful environments, not directly improving IQ; indeed, our genetic variants of interest have not been shown to have direct effects on IQ in gene discovery exercises from the genetics literature. ${ }^{34}$ The estimated coefficient of birth weight in column (1) implies that a one standard deviation increase in birth weight is associated with roughly one and a half points increase in IQ. Considering the findings in Newcombe et al. (2007), our estimated effect of birth weight is not significantly different than the finding of a one kilogram increase in birth weight being associated with a 3 point increase in IQ. For our coefficient, an increase of one kilogram (or roughly 1.5 standard deviations) is predicted to increase IQ by 2.2 points, for which the $95 \%$ confidence interval contains the Newcombe et al. estimate of 3 points.

The estimates of columns (2) and (3), which weight the estimation by the inverse of the probability of being within our base sibling sample and include sibling fixed effects, respectively, do not differ substantially from the simple OLS findings of column (1). The estimates of column (2) provide

\footnotetext{
${ }^{34}$ One assumption we make is that favorable and harmful shocks are equally distributed across the life course. This assumption implies that plastic individuals, while likely to have relatively positive responses to IQ from harmful shocks, are less likely to benefit from favorable shocks that may improve IQ. Therefore, we expect no significant direct relationship between our measure of neuroplasticity and high school IQ. Additionally, excessive neuroplasticity is hypothesized to be positively associated with harmful addictive behaviors and obsessive compulsive disorder that potentially limit the benefits of increased birth weight (Koob and Le Moal 2005, Fitzgerald et al. 2010).
} 
evidence that the significant, positive association of birth weight on IQ and the insignificant statistical association between our measure of neuroplasticity and IQ is not being driven by our sample of sibling pairs with both DNA and birth weight data. Furthermore, these findings are confirmed by within family estimation of column (3), reducing the possibility of a spurious relationship due to unobserved siblingshared genetic or environmental variables. In summary, birth weight has a positive association with IQ, while our measure of neuroplasticity has no statistical association with IQ.

Table 2 regresses birth weight on our genetic measure for neuroplasticity. The purpose of Table 2 is to establish the independence of our gene and environment. Our primary focus is on the interaction between genes for neuroplasticity and birth weight, a proxy for the early nutrition environment, with the main hypothesis being that individuals with more genetic variants related to neuroplasticity are less likely to be influenced by the early nutrition environment. Therefore, in order to ensure a true interaction, not a spurious correlation, we need to ensure that our genes of interest are not influencing our environment of interest. The estimates of Table 2 provide no evidence that the genes selected to measure neuroplasticity are influencing birth weight. Additionally, genome wide association studies provide no evidence for a significant association between our proposed neuroplasticity variants and birth weight (Freathy et al. 2010). We have no reason to believe gene-environment correlation will lead to a spurious coefficient for our gene-environment interaction investigation.

\subsection{Gene-Environment Interaction}

Figure 1 plots the relationship between birth weight and high school IQ for individuals above and below the median number of plasticity alleles. The positive association between birth weight and IQ is much more pronounced for those individuals who possess fewer than or equal to the median number of plasticity alleles. Conversely, plastic individuals do not exhibit any significant association between birth weight and IQ. The findings of Figure 1 support the differential response to the early nutrition environment based upon genotype. Furthermore, Figure 1 is in the same spirit as similar figures within 
the differential susceptibility literature. To more accurately account for the differential effect of birth weight, Figure 2 plots the coefficient of birth weight for individuals with varying numbers of plastic alleles. As is shown in Figure 2, birth weight has a positive and significant association with IQ for those individuals with less than or equal to 4 plastic alleles; however, for individuals with greater than 4 plastic variants, no positive significant effect of birth weight is found. ${ }^{35}$

The estimates of Table 3 confirm the findings of Figure 1 and also provide a basis for the geneenvironment estimation. Columns (1) and (2) show that birth weight has a positive and highly significant effect on IQ for individuals possessing less than or equal the median number of plastic alleles. The coefficient is roughly identical for both the simple OLS specification of column (1) and the within family model of column (2). For column (2), a one standard deviation increase in birth weight is associated with an increase of roughly 2 points in IQ. The magnitude of the coefficient for non-plastic individuals is slightly larger in magnitude than similar estimation found in Table 1, which includes both plastic and non-plastic siblings. ${ }^{36}$

Columns ( 3 ) and (4) replicate the estimation of columns (1) and (2) but restrict the sample to more plastic individuals. As a result, the coefficient of birth weight becomes statistically indistinguishable from zero. The findings of Table 3 support the differential impact of birth weight based upon markers for neuroplasticity: More plastic individuals gain no benefit from added birth weight, whereas less plastic individuals have a strong cognitive association to the in utero nutrition environment.

Our baseline estimating equation is explored in Table 4. The estimates of Table 4 test our main hypothesis: the effect of the early nutrition environment is moderated by individuals with flexible, or

\footnotetext{
${ }^{35}$ Section $\mathrm{F}$ within the supplementary appendix provides further support for heterogeneity in the effects of birth weight on later-life IQ.

${ }^{36} 552$ individuals, or 276 sibling pairs, are discordant for our genetic measure of neuroplasticity, representing $59 \%$ of our base sample. For birth weight, our environment of interest, 894 individuals are discordant, and for the interaction between the neuroplasticity and birth weight, 914 individuals are discordant. Separate estimation for each discordant sample is found within Supplemental Appendix A.
} 
easily repaired, neural networks. A negative coefficient on the GE interaction provides support for this hypothesis by lessening the marginal effect of birth weight, for which a positive and significant association with IQ is found in Table 1. Column (1) of Table 4 estimates Equation 1 while excluding sibling fixed effects. All signs are as expected. Importantly, the coefficient on the GE interaction is negative and significant at the $1 \%$ level. As an individual contains more and more plastic alleles, the positive marginal effect of birth weight dissipates. For the mean number of plasticity alleles, the marginal effect of birth weight is halved; while for individuals with the maximum number of plasticity alleles the marginal effect of birth weight is insignificantly different than zero.

The estimates of Table 4 support our main hypothesis. Birth weight has a positive association with IQ for less plastic individuals but does not have a lasting effect for individuals with numerous plastic alleles. Importantly, this effect is consistent is across all of our estimation specifications, providing evidence that this effect is consistent within and across families and that bias due to sample selection is unlikely. $^{37}$

Table 5 re-estimates the findings of Table 4 with two alternative measures for neuroplasticity. ${ }^{38}$ Panel A considers an indicator for those who have at least plastic allele for each neuroplasticity gene under consideration. The use of the dummy is to broadly capture the more plastic individuals. As in Table 4, the interaction between this indicator and birth weight is negative, implying that those more broadly defined plastic individuals are less affected by the early nutrition environment. Specifically for our within family estimation of column (3), the effect of birth weight on IQ is reduced by two-thirds for individuals with at least one plastic allele for each gene. For Panel B, we consider a multiplicative,

\footnotetext{
${ }^{37}$ Placebo tests confirming the role of neuroplasticity in moderating the effect of birth weight on IQ are given in Appendix E. In checking all other 3-way combinations of available SNPs within the WLS, no significant interaction is found with birth weight after Bonferroni correction.

${ }^{38}$ Alternative measures of birth weight are considered within Supplemental Appendix C. Of note, an insignificant interaction is found with a simple indicator of low birth, i.e., birth weight less than 2,500 grams. Furthermore, when using the indicator of low birth, the estimated moderation of birth weight is absent; however, the coefficient of the interaction is not precisely estimated, which implies that a moderating effect from neuroplasticity can not be ruled out. The low level of precision may in part be due to the low number of discordant siblings for the low birth indicator $(n=138)$.
} 
instead of additive, measure for our neuroplasticity genes. With our 3 neuroplasticity genes and 2 copies of each gene, the maximum number of favorable alleles is 8 . Looking at the estimates within Panel B of Table 5, again, the interaction with birth weight is negative, while the main effect of birth weight is positive. More importantly when considering the within family estimates of column (3), the marginal effect of birth weight goes to zero as the number of plastic alleles approaches the maximum. We also show in Appendix B that the results are qualitatively similar if we use each gene variant in isolation and also vary the measurement of neuroplasticity.

Given that neuroplasticity moderates the effects of birth weight on IQ, we should expect to see a similar effect on labor market outcomes, particularly wage. Table 6 considers wage, or productivity, in place of IQ. ${ }^{39}$ Our wage measure comes from the 1992-3 wave of the WLS, when the graduates and siblings are on average in their mid-fifties, a time just prior to retirement when wages are likely to be at a lifetime peak. ${ }^{40}$ Panel A of Table 6 gives the main effect of our neuroplasticity measure and birth weight on the natural log of hourly wage in 1992-3, whereas Panel B gives estimates for our geneenvironment interaction model.

For most estimations of Panel A in Table 6, our coefficients of interest, the coefficients of birth weight and neuroplasticity, are insignificantly different than zero but the sign and magnitude of the effect of birth weight is as expected. In previous papers, birth weight has been shown to have a positive and significant impact on earnings; e.g., Black et al. (2007) show that a $10 \%$ increase in birth weight is associated with a $1 \%$ increase in income. For column (3) in Panel A, our sibling fixed effects model, a $10 \%$ increase in birth weight ( $1 / 2$ a standard deviation) is associated with a $5 \%$ increase in wage, with a $1 \%$ increase contained within the $95 \%$ confidence band. The insignificance of our estimates for the

\footnotetext{
${ }^{39}$ Section D within the Supplemental Appendix replicates the findings of Table 6 with the previously specified alternative measures of neuroplasticity.

${ }^{40}$ Table D3 includes a number of other labor market outcomes for the 1992/3 and 2003/4 wave. Prior to the 1992/3 wave, few data were collected on siblings. As shown in Table D3, the coefficients of the interaction model are similar in sign for all other measures of labor market outcomes but often insignificantly different than zero.
} 
coefficient of birth weight may be tied to the relatively small sample for which we have data.

Additionally, insignificance may be due to the absence of accounting for the differential effect of birth weight from neuroplasticity genes.

For Panel B, we estimate our proposed interaction model, replacing IQ with wages later in life. The estimated associations of neuroplasticity, birth weight, and the interaction between the two variables, however, are similar to the regressions with IQ. Birth weight has a positive and statistically significant association with the wage rate, but the magnitude of this effect is dependent upon our measure for neuroplasticity. When considering the sibling fixed effects estimation of column (3), a $10 \%$ increase in birth weight is associated with roughly a $15 \%$ increase in wage for the least plastic individuals. For the median, neuroplasticity score, a $10 \%$ increase in birth weight is associated with roughly a $5 \%$ increase in wage. And for the maximum neuroplasticity score, a $10 \%$ increase in birth weight is negatively associated with wage. As with $I Q$, neuroplasticity moderates the associations between birth weight and later life outcomes.

\section{Conclusion}

This research questions the ubiquity of fetal programming for cognitive and productivity outcomes. Our hypothesis is that a portion of the population is more adaptable to early exposure to environmental insults in regards to cognitive outcomes and the basis of this resiliency stems from the genetics and biology of the developmental process. This has important consequences for our understanding of the determinants of long term outcomes, such as IQ and wages as well in our understanding of the heterogeneity of theses determining processes.

In summary, we argue that neuroplasticity, which we measure through genetic variation, moderates the impact of the early, in utero nutrition environment. Previous studies have established a strong link between birth weight and a host of economic and health outcomes. We focus on cognitive development and show that the positive association between birth weight and IQ dissipates for 
individuals who have genetic variants associated with neuroplasticity, where neuroplasticity represents an ability of the brain to correct, or adjust to, harmful prenatal environments. We extend this finding into a labor market outcome and show that the association between birth weight and productivity exhibits the same relationship to neuroplasticity as IQ. We also show our findings are quite robust to a variety of alternative measures of neuroplasticity. 


\section{References}

Almond, Chay and Lee (2005), The Costs of Low Birth Weight, Quarterly Journal of Economics, 120(3).

Almond and Currie (2011). Killing me softly: The fetal origins hypothesis. Journal of Economic Perspectives, 25(3), 153-172.

Almond and Mazumder (2011). Health Capital and the Prenatal Environment: The Effect of Ramadan Observance During Pregnancy. AEJ: Applied Economics, 3(4), 56-85.

Barker (1995). Fetal origins of coronary heart disease. British Medical Journal, 311(6998), 171-174.

Belsky (2005). Differential susceptibility to rearing influences: An evolutionary hypothesis and some evidence. In B. Ellis \& D. Bjorklund (Eds.), Origins of the social mind: Evolutionary Psychology and Child Development (pp. 139-163). New York: Guildford

Belsky et al. (2012). Polygenic risk, rapid childhood growth, and the development of obesity: Evidence from a 4-decade longitudinal study. JAMA Pediatrics, 166(6), 515-521.

Black et al. (2005). The More the Merrier? The Effect of Family Size and Birth Order on Children's Education. Quarterly Journal of Economics, 120(2), 669-700.

Black et al. (2007). From the cradle to the labor market? The effect of birth weight on adult outcomes. Quarterly Journal of Economics, 122(1), 409-439.

Black et al. (2009). Like Father, Like Son? A Note on the Intergenerational Transmission of IQ Scores. Economics Letters, 105(1), 138-140.

Carneiro and Heckman (2003). Human capital policy. In Inequality in America: What role for human capital policies? ed. James J. Heckman, Alan B. Krueger, and Benjamin M. Friedman. Cambridge, MA: MIT Press.

Caspi et al. (2003). Influence of life stress on depression: moderation by a polymorphism in the 5-HTT gene. Science, 301(5631), 386-389.

Conley and Bennett (2000). Is biology destiny? Birth weight and life chances. American Sociological Review, 65(3), 458-467.

Conley and Rauscher (2010). Genetic Interactions with prenatal social environment: Effects on academic and behavioral outcomes. Journal of Health and Social Behavior, 54(1), 109-127.

Conley et al. (2003). The Starting Gate: Birth Weight and Life Chances. Berkeley, CA: University of California Press

Conley et al. (2006). Twin differences in birth weight: The effects of genotype and prenatal environment on neonatal and post-neonatal mortality. Economics and Human Biology, 4(2), 151-183. 
Cook and Fletcher (2013). Interactive effects of in utero nutrition and genetic inheritance on cognition: New evidence using sibling comparisons. Working Paper.

Cunha et al. (2006). Interpreting the evidence on life cycle skill formation. In Handbook of the economics of education, ed. Eric A. Hanushek and Frank Welch. Amsterdam: North-Holland.

Dumman and Monteggia (2006). A Neurotrophic Model for Stress-Related Mood Disorders. Biological Psychiatry, 59(12), 1116-1127.

Figlio et al. (2013). The effects of poor neonatal health on children's cognitive development. NBER Working Paper 18846. Cambridge, MA: National Bureau of Economic Research (February).

Fitzgerald, K., Stern, E., Angstadt, M., \& others (2010). Altered function and connectivity of the medial frontal cortex in pediatric obsessive compulsive disorder. Biological Psychiatry, 68(11), 1039-1047.

Fletcher, Jason (2011). The Medium Run Educational Effects of Low Birth Weight. Economics of Education Review, 30(3): 517-527.

Fletcher, Jason and Steven Lehrer (2011). Genetic lotteries within families. Journal of Health Economics, 30(4), 647-659.

Freathy et al. (2010). Variants in ADCY5 and near CCNL1 are associated with fetal growth and birth weight. Nature Genetics, 42(5), 430-435.

Frost et al. (2003). Reorganization of Remote Cortical Regions After Ischemic Brain Injury: A Potential Substrate for Stroke Recovery. Journal of Neurophysiology, 89, 3205-3214.

Gensowski (2013). Personality, IQ, and lifetime earnings. Unpublished manuscript, University of Chicago, Department of Economics.

Hack et al. (2002). Outcomes in young adulthood for very-low-birth-weight infants. New England Journal of Medicine, 346(3), 149-157.

Heckman and Masterov (2004). The Productivity Argument for Investing in Young Children. Applied Economic Perspectives and Policies, 29(3), 446-493.

Heckman et al. (2006). The Effects of Cognitive and Noncognitive Abilities on Labor Market Outcomes and Social Behavior. Journal of Labor Economics, 24(3), 411-482.

Hewson, D. and A. Bennett. Childbirth research data: Medical reports or women's reports? American Journal of Epidemiology, 125 (3) (1987), pp. 484-491

Jaworowicz DJ, Nie J, Bonner MR, Vito D, Hutson A, Potischman N, et al. Agreement between selfreported birth weight and birth certificate weights. Journal of Developmental Origins of Health and Disease 2010; I:106-113. 
Koob, G., \& Le Moal, M. (2005). Plasticity of reward neurocircuitry and the 'dark side' of drug addiction. Nature Neuroscience, 8(11), 1442-1444

McVean et al. (2012). An integrated map of genetic variation from 1,092 human genomes. Nature, 491, 56-65.

Mizuno et al. (2000). Involvement of Brain-Derived Neurotrophic Factor in Spatial Memory Formation and Maintenance in a Radial Arm Maze Test in Rats. The Journal of Neuroscience, 20(18), 7116-7121.

National Office of Vital Statistics (1954). Vital Statistics of the United States 1950. Washington, D.C.: U.S. Government Printing Office.

Newcombe et al. (2007). Birthweight Predicts IQ: Fact or Artefact? Twin Research and Human Genetics,10(4), 581-586.

O'Sullivan, J.J., S.P. Mark, P. Louise. Parental recall of birth weight: How accurate is it? Archives of Disease in Children, 82 (2000), pp. 202-203

Pascual-Leone et al. (2005). The Plastic Human Brain Cortex. Annual Review of Neuroscience, 28, 377401.

Plomin et al. (2009). Common disorders are quantitative traits. Nature Reviews Genetics, 10(12), 872878.

Roceri et al. (2002). Early maternal deprivation reduces the expression of BDNF and NMDA receptor subunits in rat hippocampus. Molecular Psychiatry, 7, 609-616.

Rooij et al. (2010). Prenatal undernutrition and cognitive function in late adulthood. PNAS, 107, 1688116886.

Schulz (2010). The Dutch Hunger Winter and the developmental origins of health and disease. PNAS, 107(39), 16757-16758.

Stein et al. (1975). Famine and human development: The Dutch hunger winter of 1944-1945. New York, NY, US: Oxford University Press.

Teter and Ashford (2002). Neuroplasticity in Alzheimer's Disease. Journal of Neuroscience Research, 70, 402-437.

Trommer et al. (2005). ApoE isoform-specific effects on LTP: blockade by oligomeric amyloid- $\beta 1-42$. Neurobiology of Disease, 18, 75-82.

Walhovd et al. (2012). Long-term influence of normal variation in neonatal characteristics on human brain development. PNAS, 109, 20089-20094.

Witte et al. (2012). Interaction of BDNF and COMT Polymorphisms on Paired-Associative StimulationInduced Cortical Plasticity. The Journal of Neuroscience, 32(13), 4553- 4561. 
Yaw, B.P. , J.S. Vera, J.J. Steven. Maternal recall of distant pregnancy events. Journal of Clinical Epidemiology, 51 (5) (1998), pp. 399-405 


\section{Tables and Figures}

Table 1. Main Effects of Birth Weight and Neuroplasticity Genes on IQ

\begin{tabular}{|c|c|c|c|}
\hline \multicolumn{4}{|c|}{ Dependent Variable: High School IQ } \\
\hline & $(1)$ & $(2)$ & $(3)$ \\
\hline Neuroplasticity Genes & $\begin{array}{c}0.4808 \\
(0.4382)\end{array}$ & $\begin{array}{c}0.4252 \\
(0.4354)\end{array}$ & $\begin{array}{l}-0.0856 \\
(0.8055)\end{array}$ \\
\hline Standardized Birth Weight & $\begin{array}{c}1.4088^{* * *} \\
(0.4856)\end{array}$ & $\begin{array}{c}1.4045^{* * *} \\
(0.5066)\end{array}$ & $\begin{array}{l}1.3967^{* *} \\
(0.6689)\end{array}$ \\
\hline $\begin{array}{l}\text { Controls } \\
\text { Demographic and Family SES } \\
\text { Sibling Fixed Effects }\end{array}$ & $\begin{array}{l}\mathrm{Y} \\
\mathrm{N}\end{array}$ & $\begin{array}{l}\mathrm{Y} \\
\mathrm{N}\end{array}$ & $\begin{array}{l}\mathrm{Y} \\
\mathrm{Y}\end{array}$ \\
\hline $\begin{array}{l}\text { Estimation } \\
\quad \text { Weighting by Prob. of Being in Sib Sample }\end{array}$ & $\mathrm{N}$ & $\mathrm{Y}$ & $\mathrm{N}$ \\
\hline $\begin{array}{l}N \\
\text { R Sqr. }\end{array}$ & $\begin{array}{c}938 \\
0.1324 \\
\end{array}$ & $\begin{array}{c}938 \\
0.1284 \\
\end{array}$ & $\begin{array}{c}938 \\
0.6951 \\
\end{array}$ \\
\hline
\end{tabular}

Notes: (i) Neuroplasticity Genes is the additive genetic risk score of plastic alleles for APOE, BDNF, and COMT (ii) Demographic and family controls include race, sex, birth year (age), birth order, mother's education, father's education, and a score for family SES in 1957. (iii) Standard errors are clustered at the family level with *,**, and *** representing significance at the 10,5 , and $1 \%$ significance level, respectively. 
Table 2. Effects of Neuroplasticity Genes on Birth Weight

\begin{tabular}{|c|c|c|c|}
\hline \multicolumn{4}{|c|}{ Dependent Variable: Standardized Birth Weight } \\
\hline & $(1)$ & $(2)$ & $(3)$ \\
\hline Neuroplasticity Genes & $\begin{array}{c}0.0290 \\
(0.0321)\end{array}$ & $\begin{array}{c}0.0524 \\
(0.0349)\end{array}$ & $\begin{array}{c}0.0409 \\
(0.0543)\end{array}$ \\
\hline \multicolumn{4}{|l|}{ Controls } \\
\hline Demographic and Family SES & $\mathrm{Y}$ & $\mathrm{Y}$ & $\mathrm{Y}$ \\
\hline Sibling Fixed Effects & $\mathrm{N}$ & $\mathrm{N}$ & $\mathrm{Y}$ \\
\hline \multicolumn{4}{|l|}{ Estimation } \\
\hline Weighting by Prob. of Being in Sib Sample & $\mathrm{N}$ & $\mathrm{Y}$ & $\mathrm{N}$ \\
\hline$N$ & 938 & 938 & 938 \\
\hline R Sqr. & 0.0451 & 0.0577 & 0.6315 \\
\hline
\end{tabular}

Notes: (i) Neuroplasticity Genes is the additive genetic risk score of plastic alleles for APOE, BDNF, and COMT (ii)

Demographic and family controls include race, sex, birth year (age), birth order, mother's education, father's education, and a score for family SES in 1957. (iii) Standard errors are clustered at the family level with *,**, and *** representing significance at the 10,5 , and $1 \%$ significance level, respectively. 


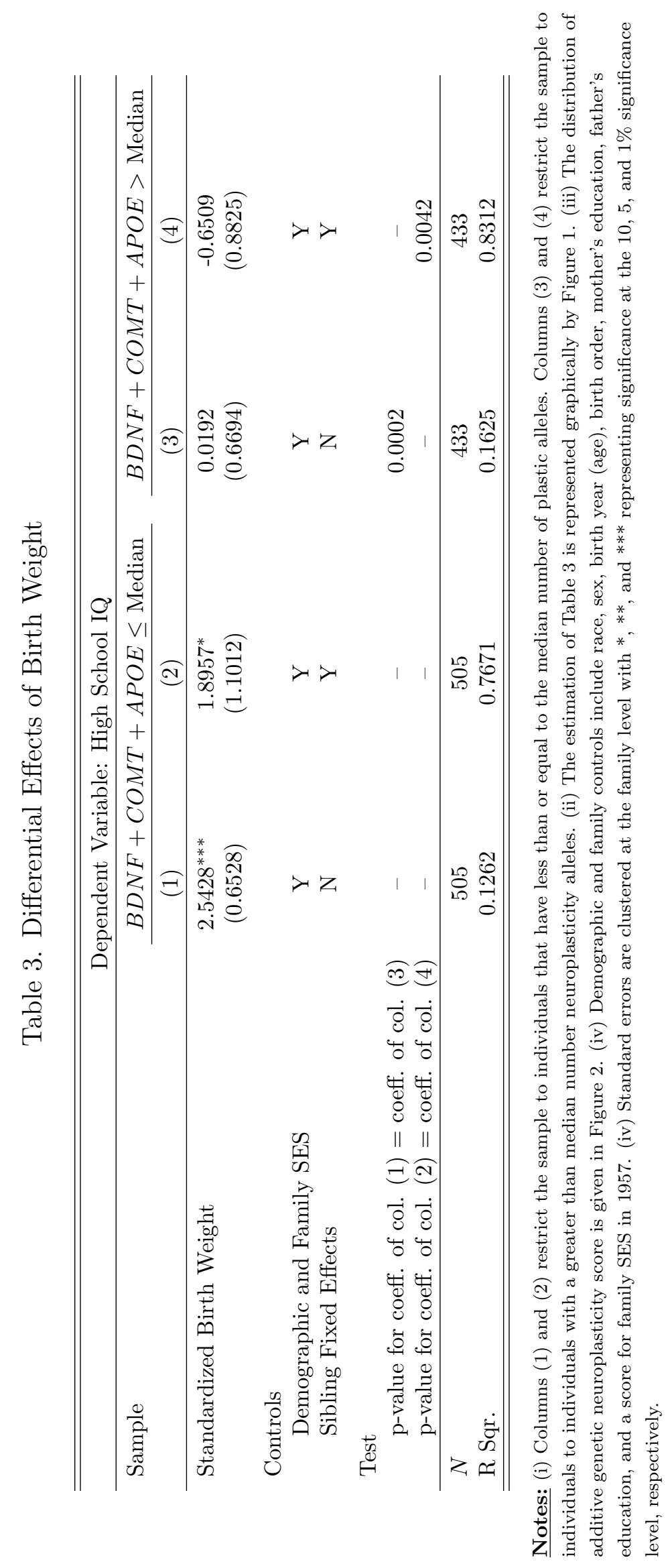


Table 4. Effect of Interaction between Birth Weight and Neuroplasticity Genes on IQ

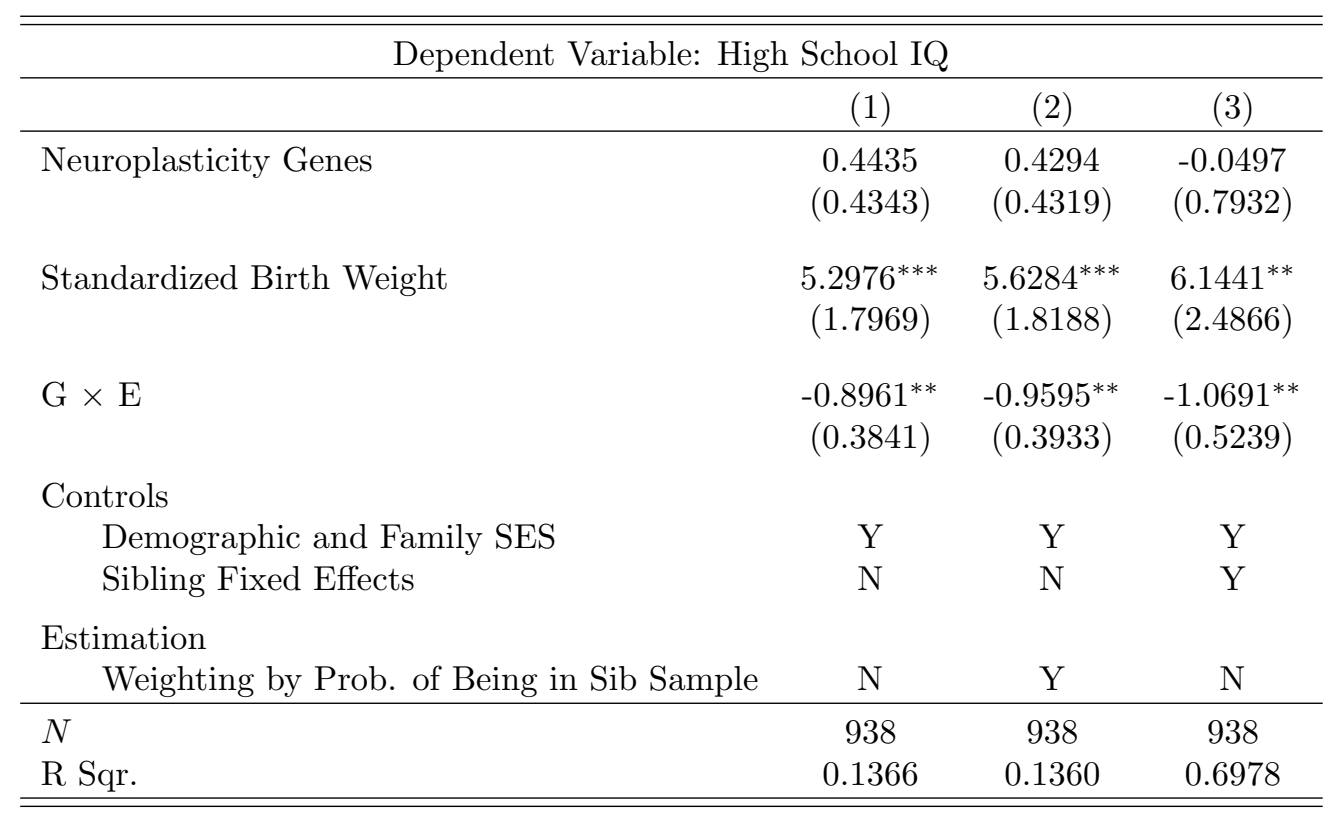

Notes: (i) Neuroplasticity Genes is the additive genetic risk score of plastic alleles for $A P O E, B D N F$, and $C O M T$. G $\times \mathrm{E}$ represents the interaction between our measure of neuroplasticity and standardized birth weight. (ii) Demographic and family controls include race, sex, birth year (age), birth order, mother's education, father's education, and a score for family SES in 1957. (vi) Standard errors are clustered at the family level with $*, * *$, and $* * *$ representing significance at the 10,5 , and $1 \%$ significance level, respectively. 
Table 5. G×E: Alternative Measures for Neuroplasticity

\begin{tabular}{|c|c|c|c|}
\hline \multicolumn{4}{|c|}{ Dependent Variable: High School IQ } \\
\hline & $(1)$ & $(2)$ & $(3)$ \\
\hline \multicolumn{4}{|c|}{ Panel A: Neuroplasticity Genes $=$ Indicator for BDNF+COMT $+A P O E>$ Median } \\
\hline Neuroplasticity Genes & $\begin{array}{c}0.9378 \\
(1.0315)\end{array}$ & $\begin{array}{c}0.8035 \\
(1.0381)\end{array}$ & $\begin{array}{c}-3.5792^{* *} \\
(1.5526)\end{array}$ \\
\hline Standardized Birth Weight & $\begin{array}{c}2.7535^{* * *} \\
(0.9134)\end{array}$ & $\begin{array}{c}3.1386^{* * *} \\
(0.9521)\end{array}$ & $\begin{array}{c}3.1751^{* * *} \\
(1.2084)\end{array}$ \\
\hline $\mathrm{G} \times \mathrm{E}$ & $\begin{array}{c}-1.8931^{*} \\
(1.0246)\end{array}$ & $\begin{array}{c}-2.3416^{* *} \\
(1.0728)\end{array}$ & $\begin{array}{c}-2.2956^{*} \\
(1.3511)\end{array}$ \\
\hline \multicolumn{4}{|l|}{ Controls } \\
\hline Demographic and Family SES & $\mathrm{Y}$ & $\mathrm{Y}$ & $\mathrm{Y}$ \\
\hline Sibling Fixed Effects & $\mathrm{N}$ & $\mathrm{N}$ & $\mathrm{Y}$ \\
\hline \multicolumn{4}{|l|}{ Estimation } \\
\hline Weighting by Prob. of Being in Sib Sample & $\mathrm{N}$ & $\mathrm{Y}$ & $\mathrm{N}$ \\
\hline$N$ & 938 & 938 & 938 \\
\hline R Sqr. & 0.1353 & 0.1357 & 0.7000 \\
\hline \multicolumn{4}{|c|}{ Panel B: Neuroplasticity Genes $=B D N F \times C O M T \times A P O E$} \\
\hline Neuroplasticity Genes & $\begin{array}{c}0.2556 \\
(0.1804)\end{array}$ & $\begin{array}{c}0.2642 \\
(0.1851)\end{array}$ & $\begin{array}{l}-0.1567 \\
(0.2963)\end{array}$ \\
\hline Standardized Birth Weight & $\begin{array}{c}2.6416^{* * *} \\
(0.7171)\end{array}$ & $\begin{array}{c}2.7838^{* * *} \\
(0.7502)\end{array}$ & $\begin{array}{c}2.8848^{* * *} \\
(0.9541)\end{array}$ \\
\hline $\mathrm{G} \times \mathrm{E}$ & $\begin{array}{c}-0.4232^{* * *} \\
(0.1578)\end{array}$ & $\begin{array}{c}-0.4574^{* * *} \\
(0.1719)\end{array}$ & $\begin{array}{c}-0.4617^{* *} \\
(0.2009)\end{array}$ \\
\hline \multicolumn{4}{|l|}{ Controls } \\
\hline Demographic and Family SES & $\mathrm{Y}$ & $\mathrm{Y}$ & $\mathrm{Y}$ \\
\hline Sibling Fixed Effects & $\mathrm{N}$ & $\mathrm{N}$ & $\mathrm{Y}$ \\
\hline \multicolumn{4}{|l|}{ Estimation } \\
\hline Weighting by Prob. of Being in Sib Sample & $\mathrm{N}$ & $\mathrm{Y}$ & $\mathrm{N}$ \\
\hline$N$ & 938 & 938 & 938 \\
\hline R Sqr. & 0.1390 & 0.1390 & 0.6985 \\
\hline
\end{tabular}

Notes: (i) For Panel A, neuroplasticity is measured by an indicator for having at least one plastic allele for each gene. For Panel $\mathrm{B}$, the multiplicative interaction of plasticity genes is used to measure neuroplasticity. $\mathrm{G} \times \mathrm{E}$ represents the interaction between each respective measure of neuroplasticity and standardized birth weight. (ii) Demographic and family controls include race, sex, birth year (age), birth order, mother's education, father's education, and a score for family SES in 1957. (vi) Standard errors are clustered at the family level with ${ }^{*},{ }^{*}$, and ${ }^{* * *}$ representing significance at the 10,5 , and $1 \%$ significance level, respectively. 
Table 6. Effect of Interaction on Productivity

\begin{tabular}{|c|c|c|c|}
\hline \multicolumn{4}{|c|}{ Dependent Variable: ln Wage Rate in 1992} \\
\hline & $(1)$ & $(2)$ & $(3)$ \\
\hline \multicolumn{4}{|c|}{ Panel A: Main Effects } \\
\hline Neuroplasticity Genes & $\begin{array}{l}-0.0634 \\
(0.0392)\end{array}$ & $\begin{array}{c}-0.0659^{*} \\
(0.0397)\end{array}$ & $\begin{array}{l}-0.0413 \\
(0.0840)\end{array}$ \\
\hline Standardized Birth Weight & $\begin{array}{c}0.0507 \\
(0.0473)\end{array}$ & $\begin{array}{c}0.0531 \\
(0.0476)\end{array}$ & $\begin{array}{c}0.0997 \\
(0.0788)\end{array}$ \\
\hline \multicolumn{4}{|l|}{ Controls } \\
\hline Demographic and Family SES & Y & $\mathrm{Y}$ & Y \\
\hline Sibling Fixed Effects & $\mathrm{N}$ & $\mathrm{N}$ & $\mathrm{Y}$ \\
\hline \multicolumn{4}{|l|}{ Estimation } \\
\hline Weighting by Prob. of Being in Sib Sample & $\mathrm{N}$ & $\mathrm{Y}$ & $\mathrm{N}$ \\
\hline$N$ & 820 & 820 & 820 \\
\hline R Sqr. & 0.0933 & 0.0957 & 0.6008 \\
\hline \multicolumn{4}{|c|}{ Panel B: Gene-Environment Interaction } \\
\hline Neuroplasticity Genes & $\begin{array}{l}-0.0613 \\
(0.0394)\end{array}$ & $\begin{array}{c}-0.0635 \\
(0.0399)\end{array}$ & $\begin{array}{c}-0.0213 \\
(0.0832)\end{array}$ \\
\hline Standardized Birth Weight & $\begin{array}{l}0.1221^{* *} \\
(0.0523)\end{array}$ & $\begin{array}{l}0.1204^{* *} \\
(0.0522)\end{array}$ & $\begin{array}{c}0.3156^{* * *} \\
(0.1030)\end{array}$ \\
\hline$G \times E$ & $\begin{array}{c}-0.0237^{*} \\
(0.0129)\end{array}$ & $\begin{array}{c}-0.0226^{*} \\
(0.0126)\end{array}$ & $\begin{array}{c}-0.0666^{* * *} \\
(0.0207)\end{array}$ \\
\hline \multicolumn{4}{|l|}{ Controls } \\
\hline Demographic and Family SES & $\mathrm{Y}$ & $\mathrm{Y}$ & $\mathrm{Y}$ \\
\hline Sibling Fixed Effects & $\mathrm{N}$ & $\mathrm{N}$ & $\mathrm{Y}$ \\
\hline \multicolumn{4}{|l|}{ Estimation } \\
\hline Weighting by Prob. of Being in Sib Sample & $\mathrm{N}$ & Y & $\mathrm{N}$ \\
\hline$N$ & 820 & 820 & 820 \\
\hline R Sqr. & 0.0950 & 0.0972 & 0.6069 \\
\hline
\end{tabular}

Notes: (i) Neuroplasticity Genes is the additive genetic risk score of plastic alleles for $A P O E, B D N F$, and $C O M T$. $\mathrm{G} \times \mathrm{E}$ represents the interaction between our measure of neuroplasticity and standardized birth weight. (ii) Demographic and family controls include race, sex, birth year (age), birth order, mother's education, father's education, and a score for family SES in 1957. (vi) Standard errors are clustered at the family level with *, **, and ${ }^{* * *}$ representing significance at the 10,5 , and $1 \%$ significance level, respectively. 
Table 6. Effect of Interaction on Productivity

\begin{tabular}{|c|c|c|c|}
\hline \multicolumn{4}{|c|}{ Dependent Variable: ln Wage Rate in 1992} \\
\hline & $(1)$ & $(2)$ & $(3)$ \\
\hline Neuroplasticity Genes & $\begin{array}{l}-0.0613 \\
(0.0394)\end{array}$ & $\begin{array}{l}-0.0635 \\
(0.0399)\end{array}$ & $\begin{array}{l}-0.0213 \\
(0.0832)\end{array}$ \\
\hline Standardized Birth Weight & $\begin{array}{l}0.1221^{* *} \\
(0.0523)\end{array}$ & $\begin{array}{l}0.1204^{* *} \\
(0.0522)\end{array}$ & $\begin{array}{c}0.3156^{* * *} \\
(0.1030)\end{array}$ \\
\hline $\mathrm{G} \times \mathrm{E}$ & $\begin{array}{l}-0.0237^{*} \\
(0.0129)\end{array}$ & $\begin{array}{l}-0.0226^{*} \\
(0.0126)\end{array}$ & $\begin{array}{r}-0.0666^{* * *} \\
(0.0207)\end{array}$ \\
\hline Controls & & & \\
\hline $\begin{array}{l}\text { Demographic and Family SES } \\
\text { Sibling Fixed Effects }\end{array}$ & $\begin{array}{l}\mathrm{Y} \\
\mathrm{N}\end{array}$ & $\begin{array}{l}\mathrm{Y} \\
\mathrm{N}\end{array}$ & $\begin{array}{l}\mathrm{Y} \\
\mathrm{Y}\end{array}$ \\
\hline $\begin{array}{l}\text { Estimation } \\
\quad \text { Weighting by Prob. of Being in Sib Sample }\end{array}$ & $\mathrm{N}$ & $\mathrm{Y}$ & $\mathrm{N}$ \\
\hline $\begin{array}{l}N \\
\text { R Sqr. }\end{array}$ & $\begin{array}{c}820 \\
0.0950\end{array}$ & $\begin{array}{c}820 \\
0.0972\end{array}$ & $\begin{array}{c}820 \\
0.6069\end{array}$ \\
\hline
\end{tabular}




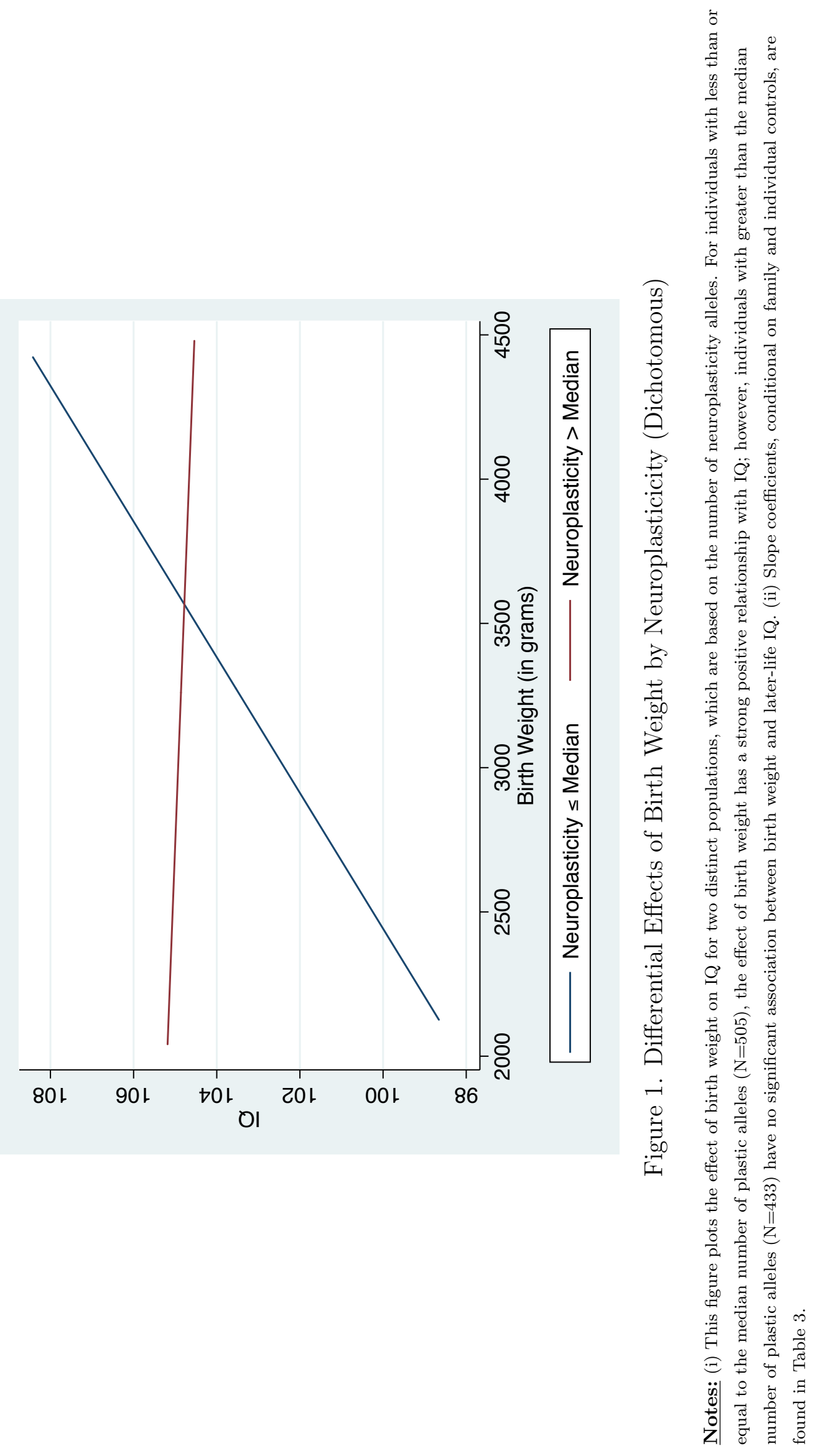




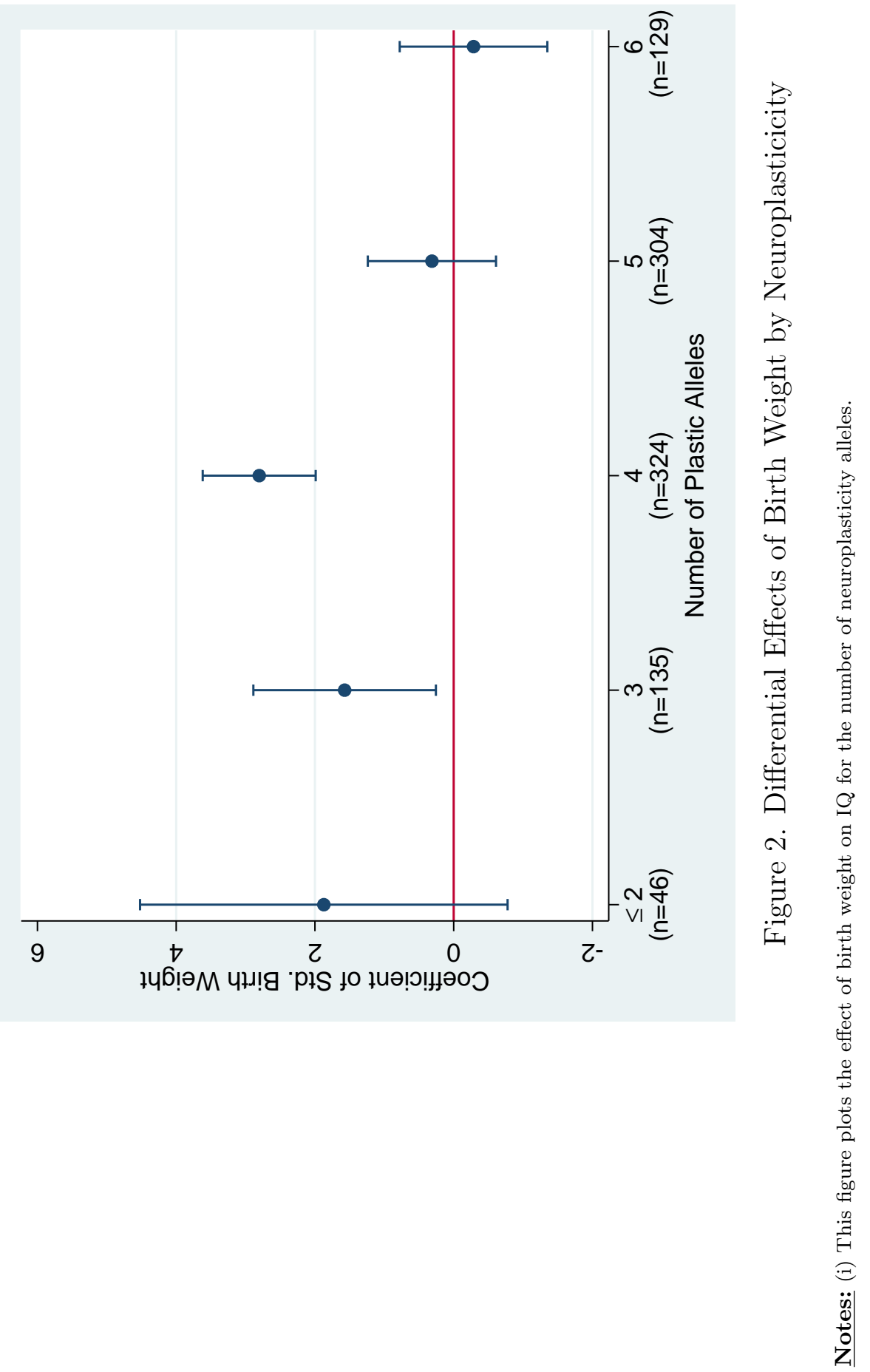




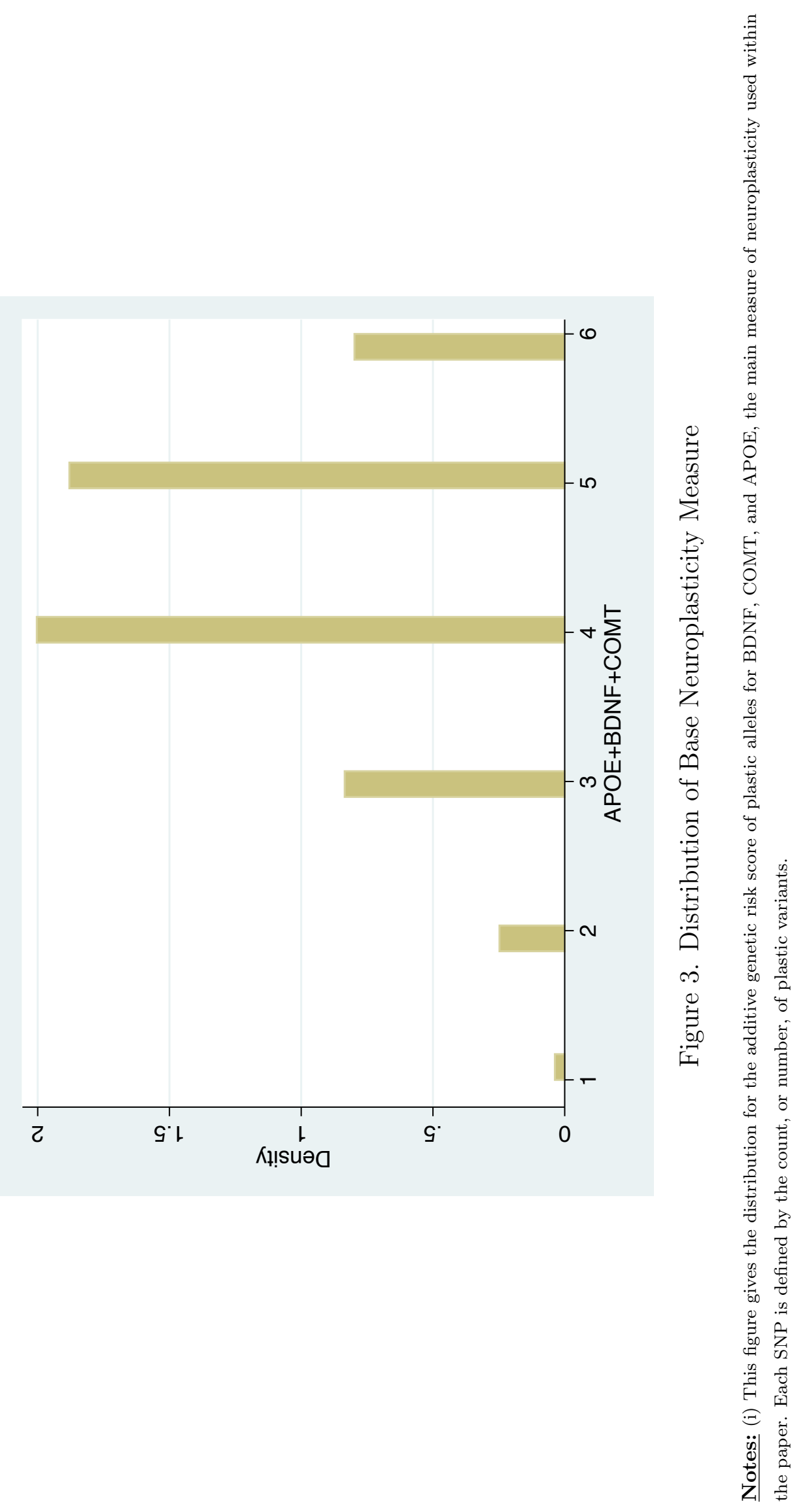




\section{Appendix A: Summary Statistics and Sample Selection}

Table A1. Summary Statistics for Differing Samples

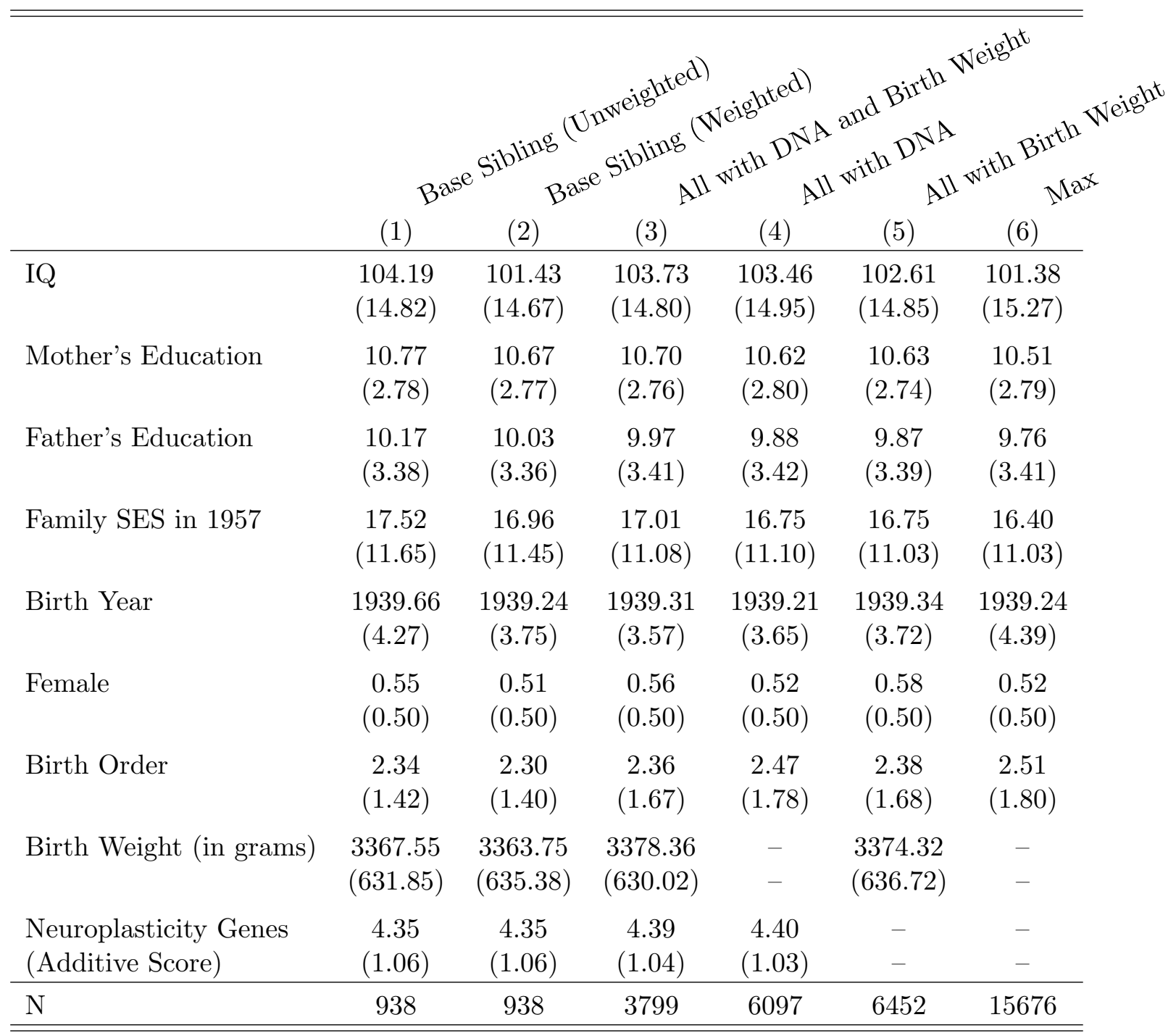

Notes: Columns (1) and (2) are comprised of our base sibling pair sample. Column (3) consists of all individuals (i.e., not pairs) that contain data for the SNPs used to measure neuroplasticity and birth weight. Column (4) consists of all individuals with data for neuroplasticity SNPs and column (5) consists of all individuals with data for birth weight. Column (6) gives sample statistics for the maximum available sample. SES is an index created from father's education, mother's education, father's occupation (Duncan SEI), and family income. 
Table A2. Summary Statistics for Differing Samples of Siblings

\begin{tabular}{lcccc}
\hline \hline & \multicolumn{4}{c}{ Siblings Pairs with Data for: } \\
\cline { 2 - 5 } & IQ & Birth Weight & DNA & BW + DNA \\
& $(1)$ & $(2)$ & $(3)$ & $(4)$ \\
\hline IQ & 101.35 & 103.25 & 104.56 & 104.19 \\
& $(15.37)$ & $(14.85)$ & $(15.02)$ & 14.82 \\
Birth Weight (in grams) & & 3394.96 & & 3367.55 \\
& & $(636.82)$ & & $(631.85)$ \\
Neuroplasticity Genes (Additive Score) & & & 4.39 & 4.35 \\
& & & $(1.04)$ & $(1.06)$ \\
Mother's Education & 10.52 & 10.75 & 10.68 & 10.77 \\
& $(2.77)$ & $(2.67)$ & $(2.78)$ & $(2.78)$ \\
Father's Education & 9.74 & 9.98 & 9.97 & 10.17 \\
\multirow{2}{*}{ Family SES in 1957 } & $(3.35)$ & $(3.37)$ & $(3.35)$ & $(3.38)$ \\
& 16.17 & 16.82 & 16.77 & 17.52 \\
Birth Year & $(10.93)$ & $(11.01)$ & $(11.26)$ & $(11.65)$ \\
Female & 1939.29 & 1939.69 & 1939.49 & 1939.66 \\
& $(4.84)$ & $(4.63)$ & $(4.52)$ & $(4.27)$ \\
Birth Order & 0.52 & 0.56 & 0.52 & 0.55 \\
& $(0.52)$ & $(0.50)$ & $(0.50)$ & $(0.50)$ \\
\hline N & 2.54 & 2.35 & 2.50 & 2.34 \\
\hline \hline
\end{tabular}

Notes: Column (1) restricts the sample to sibling pairs containing data on IQ as well as our base set of controls. Column (2) gives sample statistics for sibling pairs containing data on birth weight, while column (3) restricts the sample to sibling pairs with data for our neuroplasticity SNPs. Column (4) restricts the sample to sibling pairs with both birth weight and DNA data; this represents our base sibling sample. 
Table A3. Summary Statistics by Neuroplasticity Score

\begin{tabular}{lccccc}
\hline \hline No. of Neuroplasticity Variants: & $0-2$ & 3 & 4 & 5 & 6 \\
& $(1)$ & $(2)$ & $(3)$ & $(4)$ & $(5)$ \\
\hline IQ & 103.24 & 103.71 & 104.21 & 103.72 & 106.11 \\
& $(14.51)$ & $(14.23)$ & $(15.19)$ & $(14.94)$ & $(14.38)$ \\
Birth Weight (in grams) & 3348.32 & 3271.74 & 3380.07 & 3388.61 & 3393.59 \\
& $(627.98)$ & $(656.28)$ & $(641.75)$ & $(580.27)$ & $(696.25)$ \\
Mother's Education & 10.26 & 10.57 & 10.85 & 10.78 & 10.99 \\
& $(2.29)$ & $(2.73)$ & $(2.75)$ & $(2.86)$ & $(2.86)$ \\
Father's Education & 10.48 & 10.25 & 10.04 & 10.22 & 10.21 \\
& $(3.20)$ & $(3.33)$ & $(3.30)$ & $(3.45)$ & $(3.55)$ \\
Family SES & 19.54 & 18.94 & 17.60 & 16.68 & 17.10 \\
\multirow{2}{*}{ Birth Year } & $(10.80)$ & $(12.65)$ & $(11.75)$ & $(10.92)$ & $(12.21)$ \\
& 1939.09 & 1938.93 & 1940.12 & 1939.66 & 1939.46 \\
Female & $(3.28)$ & $(4.26)$ & $(4.60)$ & $(4.25)$ & $(3.63)$ \\
& 0.63 & 0.59 & 0.54 & 0.54 & 0.56 \\
Birth Order & $(0.49)$ & $(0.49)$ & $(0.50)$ & $(0.50)$ & $(0.50)$ \\
& 2.15 & 2.16 & 2.50 & 2.32 & 2.22 \\
N & $(1.11)$ & $(1.27)$ & $(1.64)$ & $(1.35)$ & $(1.19)$ \\
\hline \hline
\end{tabular}

Table A4. Summary Statistics: Siblings with Discordant Genotypes

\begin{tabular}{lccc}
\hline \hline & \multicolumn{3}{c}{ Siblings Pair Sample: } \\
\cline { 2 - 4 } & $\begin{array}{c}\text { Base } \\
(1)\end{array}$ & $\begin{array}{c}\text { Concordant } \\
(2)\end{array}$ & $\begin{array}{c}\text { Discordant } \\
(3)\end{array}$ \\
\hline IQ & 104.19 & 104.03 & 104.42 \\
& $(14.82)$ & $(15.04)$ & $(14.52)$ \\
Birth Weight & 3367.55 & 3386.28 & 3340.76 \\
(in grams) & 631.85 & $(623.80)$ & $(643.05)$ \\
Neuroplasticity Genes & 4.35 & 4.35 & 4.36 \\
(Count) & $(1.06)$ & $(1.10)$ & $(1.00)$ \\
\hline $\mathrm{N}$ & 938 & 386 & 552 \\
\hline \hline
\end{tabular}

Notes: This table separates the base sibling sample by differences in sibling genotypes. Column (1) gives our base sample; column (2) considers only siblings that are concordant in regards to our base neuroplasticity measure (i.e., the additive risk score of BDNF, COMT, and APOE); and column (3) gives sample statistics for siblings who differ in genotype. 
Table A5. Base Estimation: Siblings with Discordant Genotypes

\begin{tabular}{|c|c|c|c|}
\hline \multicolumn{4}{|c|}{ Dependent Variable: High School IQ } \\
\hline & (1) & $(2)$ & $(3)$ \\
\hline Neuroplasticity Genes & $\begin{array}{c}0.7779 \\
(0.5333)\end{array}$ & $\begin{array}{c}0.5907 \\
(0.5364)\end{array}$ & $\begin{array}{l}-0.1729 \\
(0.8028)\end{array}$ \\
\hline Standardized Birth Weight & $\begin{array}{c}8.4402^{* * *} \\
(2.2905)\end{array}$ & $\begin{array}{c}7.6851^{* * *} \\
(2.3009)\end{array}$ & $\begin{array}{l}6.9706^{* *} \\
(3.1306)\end{array}$ \\
\hline $\mathrm{G} \times \mathrm{E}$ & $\begin{array}{c}-1.4125^{* * *} \\
(0.4628)\end{array}$ & $\begin{array}{c}-1.2430^{* * *} \\
(0.4675)\end{array}$ & $\begin{array}{l}-1.0512 \\
(0.6579)\end{array}$ \\
\hline \multicolumn{4}{|l|}{ Controls } \\
\hline Demographic and Family SES & $\mathrm{Y}$ & $\mathrm{Y}$ & $\mathrm{Y}$ \\
\hline Sibling Fixed Effects & $\mathrm{N}$ & $\mathrm{N}$ & $\mathrm{Y}$ \\
\hline \multicolumn{4}{|l|}{ Estimation } \\
\hline$N$ & 552 & 552 & 552 \\
\hline R Sqr. & 0.1755 & 0.1737 & 0.7099 \\
\hline
\end{tabular}

Notes: This table performs our base estimation (Table 4) with sibling pairs that are discordant in regards to neuroplasticity genes.

Table A6. Summary Statistics: Siblings with Discordant Environment (Birth Weight)

\begin{tabular}{lccc}
\hline \hline & \multicolumn{3}{c}{ Siblings Pair Sample: } \\
\cline { 2 - 4 } & $\begin{array}{c}\text { Base } \\
(1)\end{array}$ & $\begin{array}{c}\text { Concordant } \\
(2)\end{array}$ & $\begin{array}{c}\text { Discordant } \\
(3)\end{array}$ \\
\hline \hline $\mathrm{IQ}$ & 104.19 & 104.16 & 104.19 \\
& $(14.82)$ & $(15.34)$ & $(14.81)$ \\
Birth Weight & 3367.55 & 3626.16 & 3354.82 \\
(in grams) & 631.85 & $(628.58)$ & $(629.62)$ \\
Neuroplasticity Genes & 4.35 & 4.47 & 4.34 \\
(Count) & $(1.06)$ & $(0.0 .85)$ & $(1.07)$ \\
\hline $\mathrm{N}$ & 938 & 44 & 894 \\
\hline \hline
\end{tabular}

Notes: This table separates the base sibling sample by differences in sibling birth weight. Column (1) gives our base sample; column (2) considers only siblings that have identical birth weights; and column (3) gives sample statistics for siblings who differ in birth weight. 
Table A7. Base Estimation: Siblings with Discordant Environment (Birth Weight)

\begin{tabular}{|c|c|c|c|}
\hline \multicolumn{4}{|c|}{ Dependent Variable: High School IQ } \\
\hline & $(1)$ & $(2)$ & $(3)$ \\
\hline Neuroplasticity Genes & $\begin{array}{c}0.4450 \\
(0.4456)\end{array}$ & $\begin{array}{c}0.3558 \\
(0.4420)\end{array}$ & $\begin{array}{l}-0.1348 \\
(0.8174)\end{array}$ \\
\hline Standardized Birth Weight & $\begin{array}{c}5.3788^{* * *} \\
(1.8519)\end{array}$ & $\begin{array}{c}5.6883^{* * *} \\
(1.7954)\end{array}$ & $\begin{array}{l}6.5211^{* *} \\
(2.5254)\end{array}$ \\
\hline $\mathrm{G} \times \mathrm{E}$ & $\begin{array}{c}-0.9212^{* *} \\
(0.3970)\end{array}$ & $\begin{array}{c}-0.9989^{* *} \\
(0.3919)\end{array}$ & $\begin{array}{c}-1.1431^{* *} \\
(0.5307)\end{array}$ \\
\hline $\begin{array}{l}\text { Controls } \\
\text { Demographic and Family SES } \\
\text { Sibling Fixed Effects }\end{array}$ & $\begin{array}{l}\mathrm{Y} \\
\mathrm{N}\end{array}$ & $\begin{array}{l}\mathrm{Y} \\
\mathrm{N}\end{array}$ & $\begin{array}{l}\mathrm{Y} \\
\mathrm{Y}\end{array}$ \\
\hline $\begin{array}{l}\text { Estimation } \\
\text { Weighting by Prob. of Being in Sib Sample }\end{array}$ & $\mathrm{N}$ & $\mathrm{Y}$ & $\mathrm{N}$ \\
\hline $\begin{array}{l}N \\
\mathrm{R} \text { Sqr. }\end{array}$ & $\begin{array}{c}894 \\
0.1391 \\
\end{array}$ & $\begin{array}{c}894 \\
0.1363 \\
\end{array}$ & $\begin{array}{c}894 \\
0.6986 \\
\end{array}$ \\
\hline
\end{tabular}

Notes: This table performs our base estimation (Table 4) with sibling pairs that are discordant in regards to birth weight.

Table A8. Summary Statistics: Siblings with Discordant Gene-Environment Interaction

\begin{tabular}{lccc}
\hline \hline & \multicolumn{3}{c}{ Siblings Pair Sample: } \\
\cline { 2 - 4 } & $\begin{array}{c}\text { Base } \\
(1)\end{array}$ & $\begin{array}{c}\text { Concordant } \\
(2)\end{array}$ & $\begin{array}{c}\text { Discordant } \\
(3)\end{array}$ \\
\hline \hline IQ & 104.19 & 110.08 & 104.04 \\
& $(14.82)$ & $(14.48)$ & $(14.81)$ \\
Birth Weight & 3367.55 & 3385.40 & 3367.08 \\
(in grams) & 631.85 & $(570.98)$ & $(633.65)$ \\
Neuroplasticity Genes & 4.35 & 4.71 & 4.34 \\
(Count) & $(1.06)$ & $(0.81)$ & $(1.06)$ \\
\hline $\mathrm{N}$ & 938 & 24 & 914 \\
\hline \hline
\end{tabular}

Notes: This table separates the base sibling sample by differences in the interaction between our neuroplasticity score and birth weight. Column (1) gives our base sample; column (2) considers only siblings that have an identical interaction; and column (3) gives sample statistics for siblings who differ. 
Table A9. Base Estimation: Siblings with Discordant Gene-Environment Interaction

\begin{tabular}{|c|c|c|c|}
\hline \multicolumn{4}{|c|}{ Dependent Variable: High School IQ } \\
\hline & (1) & $(2)$ & $(3)$ \\
\hline Neuroplasticity Genes & $\begin{array}{c}0.4477 \\
(0.4407)\end{array}$ & $\begin{array}{c}0.3700 \\
(0.4370)\end{array}$ & $\begin{array}{l}-0.0427 \\
(0.7939)\end{array}$ \\
\hline Standardized Birth Weight & $\begin{array}{c}5.0416^{* * *} \\
(1.8095)\end{array}$ & $\begin{array}{l}5.2843^{* * *} \\
(1.7511)\end{array}$ & $\begin{array}{l}6.2350^{* *} \\
(2.4978)\end{array}$ \\
\hline $\mathrm{G} \times \mathrm{E}$ & $\begin{array}{r}-0.8254^{* *} \\
(0.3873)\end{array}$ & $\begin{array}{c}-0.8925^{* *} \\
(0.3811)\end{array}$ & $\begin{array}{c}-1.0829^{* *} \\
(0.5263)\end{array}$ \\
\hline $\begin{array}{l}\text { Controls } \\
\text { Demographic and Family SES } \\
\text { Sibling Fixed Effects }\end{array}$ & $\begin{array}{l}\mathrm{Y} \\
\mathrm{N}\end{array}$ & $\begin{array}{l}\mathrm{Y} \\
\mathrm{N}\end{array}$ & $\begin{array}{l}\mathrm{Y} \\
\mathrm{Y}\end{array}$ \\
\hline $\begin{array}{l}\text { Estimation } \\
\text { Weighting by Prob. of Being in Sib Sample }\end{array}$ & $\mathrm{N}$ & $\mathrm{Y}$ & $\mathrm{N}$ \\
\hline $\begin{array}{l}N \\
\text { R Sqr. }\end{array}$ & $\begin{array}{c}914 \\
0.1386\end{array}$ & $\begin{array}{c}914 \\
0.1350\end{array}$ & $\begin{array}{c}914 \\
0.6999\end{array}$ \\
\hline
\end{tabular}

Notes: This table performs our base estimation (Table 4) with sibling pairs that are discordant in regards to the interaction between birth weight and the base measure (i.e., interaction) of neuroplasticity genes. 


\section{Appendix B: Effects of Individual SNPs}

\section{Table B1. BDNF}

\begin{tabular}{|c|c|c|c|}
\hline \multicolumn{4}{|c|}{ Dependent Variable: High School IQ } \\
\hline & $(1)$ & $(2)$ & $(3)$ \\
\hline \multicolumn{4}{|c|}{ Panel A: BDNF = Categorical } \\
\hline $\mathrm{BDNF}$ & $\begin{array}{c}0.0045 \\
(0.8455)\end{array}$ & $\begin{array}{c}0.0708 \\
(0.8282)\end{array}$ & $\begin{array}{c}1.4912 \\
(1.2867)\end{array}$ \\
\hline Standardized Birth Weight & $\begin{array}{c}2.0633 \\
(1.6560)\end{array}$ & $\begin{array}{c}1.3300 \\
(1.5164)\end{array}$ & $\begin{array}{c}2.7466 \\
(2.0975)\end{array}$ \\
\hline $\mathrm{G} \times \mathrm{E}$ & $\begin{array}{l}-0.3912 \\
(0.9269)\end{array}$ & $\begin{array}{c}0.0604 \\
(0.8776)\end{array}$ & $\begin{array}{c}-0.8219 \\
(1.1457)\end{array}$ \\
\hline \multicolumn{4}{|l|}{ Controls } \\
\hline Demographic and Family SES & $\mathrm{Y}$ & $\mathrm{Y}$ & $\mathrm{Y}$ \\
\hline Sibling Fixed Effects & $\mathrm{N}$ & $\mathrm{N}$ & $\mathrm{Y}$ \\
\hline \multicolumn{4}{|l|}{ Estimation } \\
\hline Weighting by Prob. of Being in Sib Sample & $\mathrm{N}$ & $\mathrm{Y}$ & $\mathrm{N}$ \\
\hline$N$ & 938 & 938 & 938 \\
\hline R Sqr. & 0.1314 & 0.1274 & 0.6964 \\
\hline \multicolumn{4}{|c|}{ Panel B: BDNF = Indicator for at Least One Plastic Allele } \\
\hline $\mathrm{BDNF}$ & $\begin{array}{l}-2.7718 \\
(2.1192)\end{array}$ & $\begin{array}{c}-3.2794^{*} \\
(1.9548)\end{array}$ & $\begin{array}{l}-1.2093 \\
(2.4292)\end{array}$ \\
\hline Standardized Birth Weight & $\begin{array}{l}4.9296^{*} \\
(2.8294)\end{array}$ & $\begin{array}{l}4.9697^{*} \\
(2.5840)\end{array}$ & $\begin{array}{c}1.3985 \\
(3.5031)\end{array}$ \\
\hline $\mathrm{G} \times \mathrm{E}$ & $\begin{array}{l}-3.5965 \\
(2.8408)\end{array}$ & $\begin{array}{l}-3.6098 \\
(2.6162)\end{array}$ & $\begin{array}{c}0.0130 \\
(3.5019)\end{array}$ \\
\hline \multicolumn{4}{|l|}{ Controls } \\
\hline Demographic and Family SES & $\mathrm{Y}$ & $\mathrm{Y}$ & $\mathrm{Y}$ \\
\hline Sibling Fixed Effects & $\mathrm{N}$ & $\mathrm{N}$ & $\mathrm{Y}$ \\
\hline \multicolumn{4}{|l|}{ Estimation } \\
\hline Weighting by Prob. of Being in Sib Sample & $\mathrm{N}$ & $\mathrm{Y}$ & $\mathrm{N}$ \\
\hline$N$ & 938 & 938 & 938 \\
\hline R Sqr. & 0.1336 & 0.1300 & 0.6952 \\
\hline \multicolumn{4}{|c|}{ Panel $C: B D N F=$ Indicator for Two Plastic Alleles } \\
\hline BDNF & $\begin{array}{c}0.4237 \\
(1.0152)\end{array}$ & $\begin{array}{c}0.5419 \\
(1.0186)\end{array}$ & $\begin{array}{c}2.3319 \\
(1.5569)\end{array}$ \\
\hline Standardized Birth Weight & $\begin{array}{c}1.4989^{*} \\
(0.8716)\end{array}$ & $\begin{array}{c}1.1763 \\
(0.8106)\end{array}$ & $\begin{array}{l}2.3262^{*} \\
(1.1860)\end{array}$ \\
\hline $\mathrm{G} \times \mathrm{E}$ & $\begin{array}{l}-0.1269 \\
(1.0035)\end{array}$ & $\begin{array}{c}0.3736 \\
(0.9824)\end{array}$ & $\begin{array}{l}-1.3270 \\
(1.3111)\end{array}$ \\
\hline \multicolumn{4}{|l|}{ Controls } \\
\hline Demographic and Family SES & $\mathrm{Y}$ & $\mathrm{Y}$ & $\mathrm{Y}$ \\
\hline Sibling Fixed Effects & $\mathrm{N}$ & $\mathrm{N}$ & $\mathrm{Y}$ \\
\hline \multicolumn{4}{|l|}{ Estimation } \\
\hline Weighting by Prob. of Being in Sib Sample & $\mathrm{N}$ & $\mathrm{Y}$ & $\mathrm{N}$ \\
\hline$N$ & 938 & 938 & 938 \\
\hline R Sqr. & 0.1314 & 0.1279 & 0.6974 \\
\hline
\end{tabular}

Notes: (i) This table performs our base estimation (Table 4) while restricting our neuroplasticity measure solely to the SNP of BDNF. Panel A uses the count of plastic alleles (i.e., 0, 1, 2); Panel B uses an indicator for individuals who have at least one plastic variant; and Panel $\mathrm{C}$ uses an indicator for individuals containing two plastic variants. (ii) For our base sibling sample, $4.69 \%(\mathrm{~N}=44)$ do not carry a plastic variant of BDNF, $29.64 \%(\mathrm{~N}=278)$ carry one plastic variant, and $65.67 \%(\mathrm{~N}=616)$ carry two 
Table B2. COMT

\begin{tabular}{|c|c|c|c|}
\hline \multicolumn{4}{|c|}{ Dependent Variable: High School IQ } \\
\hline & $(1)$ & $(2)$ & $(3)$ \\
\hline \multicolumn{4}{|c|}{ Panel A: COMT = Categorical } \\
\hline COMT & $\begin{array}{c}1.0489 \\
(0.6678)\end{array}$ & $\begin{array}{c}0.9765 \\
(0.6726)\end{array}$ & $\begin{array}{l}-1.6149 \\
(1.1147)\end{array}$ \\
\hline Standardized Birth Weight & $\begin{array}{c}2.6407^{* * *} \\
(0.8509)\end{array}$ & $\begin{array}{c}2.9524^{* * *} \\
(0.8691)\end{array}$ & $\begin{array}{c}3.3930^{* * *} \\
(1.2145)\end{array}$ \\
\hline $\mathrm{G} \times \mathrm{E}$ & $\begin{array}{c}-1.1894^{*} \\
(0.6351)\end{array}$ & $\begin{array}{c}-1.5307^{* *} \\
(0.6458)\end{array}$ & $\begin{array}{c}-1.8397^{* *} \\
(0.8589)\end{array}$ \\
\hline \multicolumn{4}{|l|}{ Controls } \\
\hline Demographic and Family SES & $\mathrm{Y}$ & $\mathrm{Y}$ & $\mathrm{Y}$ \\
\hline Sibling Fixed Effects & $\mathrm{N}$ & $\mathrm{N}$ & $\mathrm{Y}$ \\
\hline \multicolumn{4}{|l|}{ Estimation } \\
\hline Weighting by Prob. of Being in Sib Sample & $\mathrm{N}$ & $\mathrm{Y}$ & $\mathrm{N}$ \\
\hline$N$ & 938 & 938 & 938 \\
\hline R Sqr. & 0.1369 & 0.1355 & 0.6997 \\
\hline \multicolumn{4}{|c|}{ Panel B: COMT = Indicator for at Least One Plastic Allele } \\
\hline COMT & $\begin{array}{c}1.4789 \\
(1.1055)\end{array}$ & $\begin{array}{c}1.5582 \\
(1.0928)\end{array}$ & $\begin{array}{c}-3.4361^{*} \\
(1.7655)\end{array}$ \\
\hline Standardized Birth Weight & $\begin{array}{c}2.5994^{* * *} \\
(1.0046)\end{array}$ & $\begin{array}{c}3.1344^{* * *} \\
(0.9907)\end{array}$ & $\begin{array}{l}3.4404^{* *} \\
(1.4300)\end{array}$ \\
\hline $\mathrm{G} \times \mathrm{E}$ & $\begin{array}{l}-1.5578 \\
(1.1247)\end{array}$ & $\begin{array}{c}-2.3100^{* *} \\
(1.1157)\end{array}$ & $\begin{array}{c}-2.5871 \\
(1.5713)\end{array}$ \\
\hline \multicolumn{4}{|l|}{ Controls } \\
\hline Demographic and Family SES & $\mathrm{Y}$ & $\mathrm{Y}$ & $\mathrm{Y}$ \\
\hline Sibling Fixed Effects & $\mathrm{N}$ & $\mathrm{N}$ & $\mathrm{Y}$ \\
\hline \multicolumn{4}{|l|}{ Estimation } \\
\hline Weighting by Prob. of Being in Sib Sample & $\mathrm{N}$ & $\mathrm{Y}$ & $\mathrm{N}$ \\
\hline$N$ & 938 & 938 & 938 \\
\hline R Sqr. & 0.1350 & 0.1344 & 0.7000 \\
\hline \multicolumn{4}{|c|}{ Panel C: COMT = Indicator for Two Plastic Alleles } \\
\hline COMT & $\begin{array}{c}1.3402 \\
(1.0634)\end{array}$ & $\begin{array}{c}1.1163 \\
(1.0933)\end{array}$ & $\begin{array}{l}-0.3986 \\
(1.6125)\end{array}$ \\
\hline Standardized Birth Weight & $\begin{array}{c}1.8700^{* * *} \\
(0.5700)\end{array}$ & $\begin{array}{c}1.8991^{* * *} \\
(0.6173)\end{array}$ & $\begin{array}{c}2.1001^{* * *} \\
(0.7648)\end{array}$ \\
\hline $\mathrm{G} \times \mathrm{E}$ & $\begin{array}{c}-1.6594^{*} \\
(0.9524)\end{array}$ & $\begin{array}{c}-1.8289^{*} \\
(1.0270)\end{array}$ & $\begin{array}{c}-2.3244^{*} \\
(1.2367)\end{array}$ \\
\hline \multicolumn{4}{|l|}{ Controls } \\
\hline Demographic and Family SES & $\mathrm{Y}$ & $\mathrm{Y}$ & $\mathrm{Y}$ \\
\hline Sibling Fixed Effects & $\mathrm{N}$ & $\mathrm{N}$ & $\mathrm{Y}$ \\
\hline \multicolumn{4}{|l|}{ Estimation } \\
\hline Weighting by Prob. of Being in Sib Sample & $\mathrm{N}$ & $\mathrm{Y}$ & $\mathrm{N}$ \\
\hline$N$ & 938 & 938 & 938 \\
\hline R Sqr. & 0.1351 & 0.1316 & 0.6972 \\
\hline
\end{tabular}

Notes: (i) This table performs our base estimation (Table 4) while restricting our neuroplasticity measure solely to the SNP of COMT. Panel A uses the count of plastic alleles (i.e., 0, 1, 2); Panel B uses an indicator for individuals who have at least one plastic variant; and Panel $\mathrm{C}$ uses an indicator for individuals containing two plastic variants. (ii) For our base sibling sample, $24.2 \%(\mathrm{~N}=227)$ do not carry a plastic variant of COMT, $49.36 \%(\mathrm{~N}=463)$ carry one plastic variant, and $26.44 \%(\mathrm{~N}=248)$ carry two plastic variants. 
Table B3. APOE

\begin{tabular}{|c|c|c|c|}
\hline \multicolumn{4}{|c|}{ Dependent Variable: High School IQ } \\
\hline & $(1)$ & $(2)$ & $(3)$ \\
\hline \multicolumn{4}{|c|}{ Panel A: $A P O E=$ Categorical (Number of Non-E4 Variants) } \\
\hline APOE & $\begin{array}{c}-0.1234 \\
(0.9378)\end{array}$ & $\begin{array}{l}-0.4261 \\
(0.9589)\end{array}$ & $\begin{array}{c}0.4813 \\
(1.6044)\end{array}$ \\
\hline Standardized Birth Weight & $\begin{array}{l}3.5779^{* *} \\
(1.4039)\end{array}$ & $\begin{array}{l}3.5566^{* *} \\
(1.4047)\end{array}$ & $\begin{array}{c}2.0827 \\
(1.6848)\end{array}$ \\
\hline $\mathrm{G} \times \mathrm{E}$ & $\begin{array}{l}-1.2753 \\
(0.7990)\end{array}$ & $\begin{array}{l}-1.2529 \\
(0.8110)\end{array}$ & $\begin{array}{l}-0.4037 \\
(0.9818)\end{array}$ \\
\hline \multicolumn{4}{|l|}{ Controls } \\
\hline Demographic and Family SES & $\mathrm{Y}$ & $\mathrm{Y}$ & $\mathrm{Y}$ \\
\hline Sibling Fixed Effects & $\mathrm{N}$ & $\mathrm{N}$ & $\mathrm{Y}$ \\
\hline \multicolumn{4}{|l|}{ Estimation } \\
\hline Weighting by Prob. of Being in Sib Sample & $\mathrm{N}$ & $\mathrm{Y}$ & $\mathrm{N}$ \\
\hline$N$ & 938 & 938 & 938 \\
\hline R Sqr. & 0.1333 & 0.1297 & 0.6953 \\
\hline \multicolumn{4}{|c|}{ Panel B: APOE = Indicator for at Least One Plastic Allele (Non-E4) } \\
\hline APOE & $\begin{array}{c}1.1955 \\
(2.7048)\end{array}$ & $\begin{array}{c}0.3517 \\
(2.7389)\end{array}$ & $\begin{array}{c}-6.2198 \\
(5.6859)\end{array}$ \\
\hline Standardized Birth Weight & $\begin{array}{l}4.4718^{* *} \\
(2.0865)\end{array}$ & $\begin{array}{l}4.4955^{* *} \\
(1.9976)\end{array}$ & $\begin{array}{c}6.8658^{* * *} \\
(1.7918)\end{array}$ \\
\hline $\mathrm{G} \times \mathrm{E}$ & $\begin{array}{l}-3.1892 \\
(2.1399)\end{array}$ & $\begin{array}{l}-3.2164 \\
(2.0655)\end{array}$ & $\begin{array}{c}-5.7101^{* * *} \\
(1.8993)\end{array}$ \\
\hline \multicolumn{4}{|l|}{ Controls } \\
\hline Demographic and Family SES & $\mathrm{Y}$ & Y & $\mathrm{Y}$ \\
\hline Sibling Fixed Effects & $\mathrm{N}$ & $\mathrm{N}$ & $\mathrm{Y}$ \\
\hline \multicolumn{4}{|l|}{ Estimation } \\
\hline Weighting by Prob. of Being in Sib Sample & $\mathrm{N}$ & $\mathrm{Y}$ & $\mathrm{N}$ \\
\hline$N$ & 938 & 938 & 938 \\
\hline R Sqr. & 0.1333 & 0.1296 & 0.6977 \\
\hline \multicolumn{4}{|c|}{ Panel C: $A P O E=$ Indicator for Two Plastic Alleles (Non-E4) } \\
\hline APOE & $\begin{array}{c}-0.3011 \\
(1.1024)\end{array}$ & $\begin{array}{c}-0.5955 \\
(1.1229)\end{array}$ & $\begin{array}{c}0.9848 \\
(1.6938)\end{array}$ \\
\hline Standardized Birth Weight & $\begin{array}{c}2.3399^{* * *} \\
(0.8616)\end{array}$ & $\begin{array}{c}2.3142^{* * *} \\
(0.8678)\end{array}$ & $\begin{array}{c}1.2145 \\
(1.0849)\end{array}$ \\
\hline $\mathrm{G} \times \mathrm{E}$ & $\begin{array}{l}-1.2527 \\
(1.0125)\end{array}$ & $\begin{array}{l}-1.1944 \\
(1.0383)\end{array}$ & $\begin{array}{c}0.2811 \\
(1.2910)\end{array}$ \\
\hline \multicolumn{4}{|l|}{ Controls } \\
\hline Demographic and Family SES & $\mathrm{Y}$ & $\mathrm{Y}$ & $\mathrm{Y}$ \\
\hline Sibling Fixed Effects & $\mathrm{N}$ & $\mathrm{N}$ & $\mathrm{Y}$ \\
\hline \multicolumn{4}{|l|}{ Estimation } \\
\hline Weighting by Prob. of Being in Sib Sample & $\mathrm{N}$ & $\mathrm{Y}$ & $\mathrm{N}$ \\
\hline$N$ & 938 & 938 & 938 \\
\hline R Sqr. & 0.1326 & 0.1290 & 0.6954 \\
\hline
\end{tabular}

Notes: (i) This table performs our base estimation (Table 4) while restricting our neuroplasticity measure solely to the SNP of APOE. For APOE, plastic variants are defined as not having the E4 variant. Panel A uses the count of plastic alleles (i.e., 0, 1, 2); Panel B uses an indicator for individuals who have at least one plastic variant; and Panel $\mathrm{C}$ uses an indicator for individuals containing two plastic variants. (ii) For our base sibling sample, 2.35\% ( $\mathrm{N}=22)$ carry 2 copies of the $\mathrm{E} 4$ variant, $23.45 \%(\mathrm{~N}=220)$ carry one copy of the $\mathrm{E} 4$ variant, and $74.2 \%(\mathrm{~N}=696)$ carry no copies of the $\mathrm{E} 4$ variant. 
Table B4. Alternative Interactions between BDNF, COMT, and APOE

\begin{tabular}{|c|c|c|c|}
\hline \multicolumn{4}{|c|}{ Dependent Variable: High School IQ } \\
\hline & $(1)$ & $(2)$ & $(3)$ \\
\hline \multicolumn{4}{|c|}{ Panel A: BDNF+COMT } \\
\hline $\mathrm{BDNF} \times \mathrm{COMT}$ & $\begin{array}{c}0.5647 \\
(0.5068)\end{array}$ & $\begin{array}{c}0.5477 \\
(0.5018)\end{array}$ & $\begin{array}{l}-0.2785 \\
(0.9250)\end{array}$ \\
\hline Standardized Birth Weight & $\begin{array}{l}3.4547^{* *} \\
(1.3849)\end{array}$ & $\begin{array}{c}3.5336^{* * *} \\
(1.3462)\end{array}$ & $\begin{array}{l}5.0920^{* *} \\
(2.0721)\end{array}$ \\
\hline $\mathrm{G} \times \mathrm{E}$ & $\begin{array}{l}-0.7729^{*} \\
(0.4546)\end{array}$ & $\begin{array}{l}-0.8169^{*} \\
(0.4435)\end{array}$ & $\begin{array}{r}-1.3350^{* *} \\
(0.6701)\end{array}$ \\
\hline \multicolumn{4}{|l|}{ Controls } \\
\hline Demographic and Family SES & $\mathrm{Y}$ & $\mathrm{Y}$ & $\mathrm{Y}$ \\
\hline Sibling Fixed Effects & $\mathrm{N}$ & $\mathrm{N}$ & $\mathrm{Y}$ \\
\hline \multicolumn{4}{|l|}{ Estimation } \\
\hline Weighting by Prob. of Being in Sib Sample & $\mathrm{N}$ & $\mathrm{Y}$ & $\mathrm{N}$ \\
\hline$N$ & 938 & 938 & 938 \\
\hline R Sqr. & 0.1351 & 0.1318 & 0.6985 \\
\hline \multicolumn{4}{|c|}{ Panel B: BDNF + APOE } \\
\hline $\mathrm{BDNF} \times \mathrm{APOE}$ & $\begin{array}{l}-0.0980 \\
(0.5973)\end{array}$ & $\begin{array}{l}-0.1845 \\
(0.6020)\end{array}$ & $\begin{array}{c}1.1247 \\
(1.0024)\end{array}$ \\
\hline Standardized Birth Weight & $\begin{array}{l}4.3016^{* *} \\
(2.0475)\end{array}$ & $\begin{array}{l}3.5880^{*} \\
(2.0295)\end{array}$ & $\begin{array}{c}3.4296 \\
(2.5690)\end{array}$ \\
\hline $\mathrm{G} \times \mathrm{E}$ & $\begin{array}{l}-0.8654 \\
(0.5909)\end{array}$ & $\begin{array}{l}-0.6508 \\
(0.6058)\end{array}$ & $\begin{array}{l}-0.6052 \\
(0.7429)\end{array}$ \\
\hline \multicolumn{4}{|l|}{ Controls } \\
\hline Demographic and Family SES & $\mathrm{Y}$ & $\mathrm{Y}$ & $\mathrm{Y}$ \\
\hline Sibling Fixed Effects & $\mathrm{N}$ & $\mathrm{N}$ & $\mathrm{Y}$ \\
\hline \multicolumn{4}{|l|}{ Estimation } \\
\hline Weighting by Prob. of Being in Sib Sample & $\mathrm{N}$ & $\mathrm{Y}$ & $\mathrm{N}$ \\
\hline$N$ & 938 & 938 & 938 \\
\hline R Sqr. & 0.1331 & 0.1285 & 0.6964 \\
\hline \multicolumn{4}{|c|}{ Panel C: $C O M T+A P O E$} \\
\hline $\mathrm{COMT} \times \mathrm{APOE}$ & $\begin{array}{c}0.7471 \\
(0.5472)\end{array}$ & $\begin{array}{c}0.6330 \\
(0.5456)\end{array}$ & $\begin{array}{l}-0.8228 \\
(0.8870)\end{array}$ \\
\hline Standardized Birth Weight & $\begin{array}{c}4.6887^{* * *} \\
(1.4842)\end{array}$ & $\begin{array}{c}5.3457^{* * *} \\
(1.4782)\end{array}$ & $\begin{array}{c}4.7813^{* *} \\
(1.8611)\end{array}$ \\
\hline $\mathrm{G} \times \mathrm{E}$ & $\begin{array}{c}-1.2046^{* *} \\
(0.5042)\end{array}$ & $\begin{array}{c}-1.4562^{* * *} \\
(0.5024)\end{array}$ & $\begin{array}{r}-1.2313^{* *} \\
(0.6178)\end{array}$ \\
\hline \multicolumn{4}{|l|}{ Controls } \\
\hline Demographic and Family SES & $\mathrm{Y}$ & $\mathrm{Y}$ & $\mathrm{Y}$ \\
\hline Sibling Fixed Effects & $\mathrm{N}$ & $\mathrm{N}$ & $\mathrm{Y}$ \\
\hline \multicolumn{4}{|l|}{ Estimation } \\
\hline Weighting by Prob. of Being in Sib Sample & $\mathrm{N}$ & $\mathrm{Y}$ & $\mathrm{N}$ \\
\hline$N$ & 938 & 938 & 938 \\
\hline R Sqr. & 0.1382 & 0.1366 & 0.6981 \\
\hline
\end{tabular}

Notes: This table performs our base estimation (Table 4) with differing interactions between our 3 neuroplasticity genes. Panel A considers the additive score between BDNF and COMT, Panel B considers the additive score between BDNF and APOE, and Panel $\mathrm{C}$ uses the additive score between COMT and APOE. 


\section{Appendix C: Alternate Measures of Birth Weight}

\section{Table C1. Alternative Measures of Birth Weight}

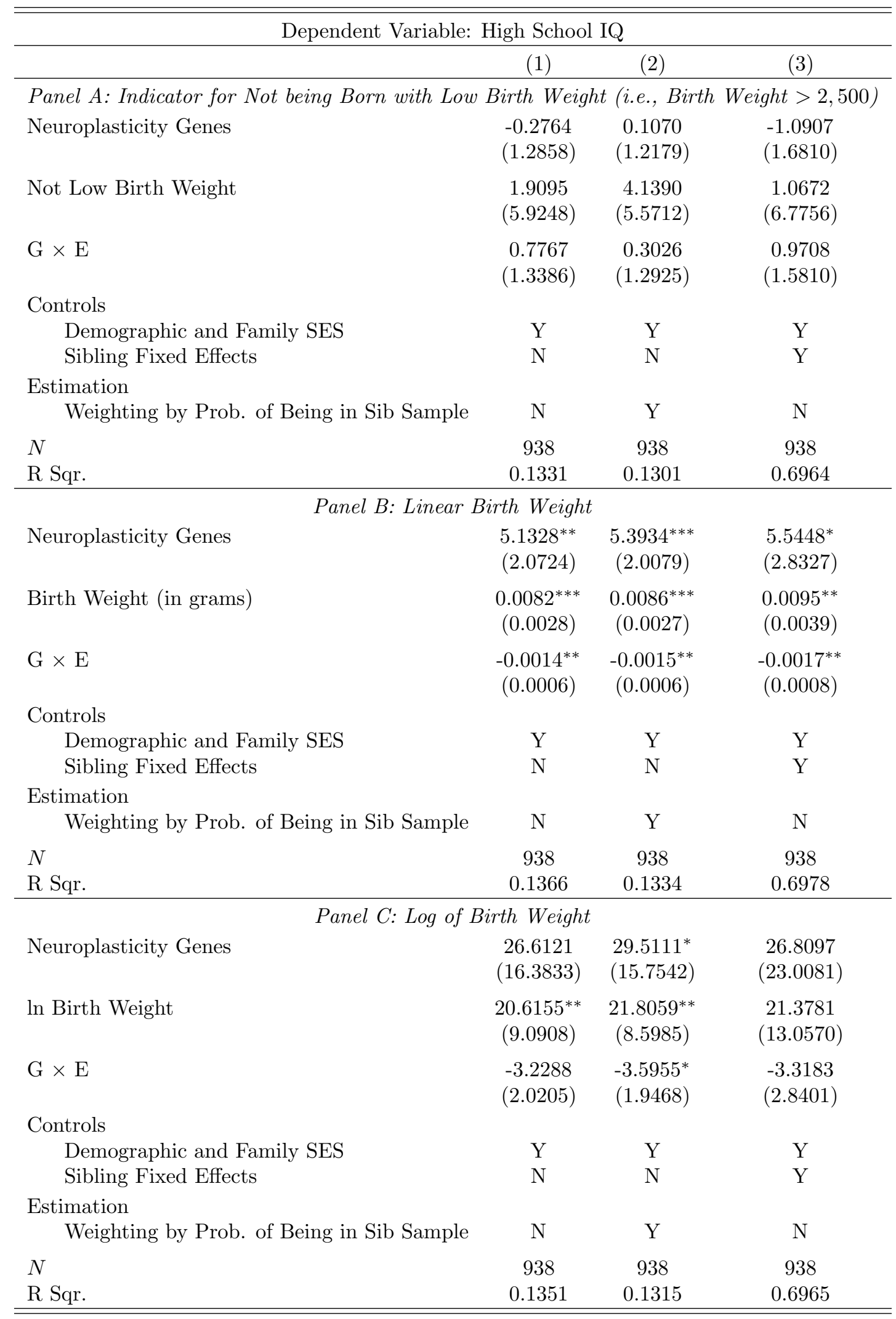

Notes: This table performs our base estimation (Table 4) with alternative measures of birth weight. Our base measure of birth weight is the standard score of birth weight given in grams. Panel A defines birth weight by an indicator for individuals not born of low birth weight (i.e., 2500 grams). Roughly $8 \%$ of our base sibling sample is born under 2,500 grams. Panel B uses unadjusted measure of birth weight given in grams. And Panel C uses the natural log of birth weight. 
Table C2. Baseline Interaction Controlling for Non-Linear Effects of Birth Weight: Quadratic

\begin{tabular}{|c|c|c|c|}
\hline \multicolumn{4}{|c|}{ Dependent Variable: High School IQ } \\
\hline & $(1)$ & $(2)$ & $(3)$ \\
\hline Neuroplasticity Genes & $\begin{array}{c}0.4423 \\
(0.4344)\end{array}$ & $\begin{array}{c}0.3691 \\
(0.4322)\end{array}$ & $\begin{array}{l}-0.0627 \\
(0.7926)\end{array}$ \\
\hline Standardized Birth Weight & $\begin{array}{c}5.0424^{* * *} \\
(1.9317)\end{array}$ & $\begin{array}{c}5.3704^{* * *} \\
(1.8856)\end{array}$ & $\begin{array}{l}5.7055^{* *} \\
(2.6344)\end{array}$ \\
\hline Standardized Birth Weight Sqr. & $\begin{array}{l}-0.1074 \\
(0.1951)\end{array}$ & $\begin{array}{c}-0.0690 \\
(0.2256)\end{array}$ & $\begin{array}{l}-0.1761 \\
(0.2472)\end{array}$ \\
\hline $\mathrm{G} \times \mathrm{E}$ & $\begin{array}{c}-0.8377^{* *} \\
(0.4208)\end{array}$ & $\begin{array}{c}-0.9231^{* *} \\
(0.4158)\end{array}$ & $\begin{array}{r}-0.9680^{*} \\
(0.5570)\end{array}$ \\
\hline \multicolumn{4}{|l|}{ Controls } \\
\hline Demographic and Family SES & $\mathrm{Y}$ & $\mathrm{Y}$ & $\mathrm{Y}$ \\
\hline Sibling Fixed Effects & $\mathrm{N}$ & $\mathrm{N}$ & $\mathrm{Y}$ \\
\hline \multicolumn{4}{|l|}{ Estimation } \\
\hline Weighting by Prob. of Being in Sib Sample & $\mathrm{N}$ & $\mathrm{Y}$ & $\mathrm{N}$ \\
\hline$N$ & 938 & 938 & 938 \\
\hline R Sqr. & 0.1368 & 0.1335 & 0.6981 \\
\hline
\end{tabular}

Notes: (i) Neuroplasticity Genes is the additive genetic risk score of plastic alleles for $A P O E, B D N F$, and $C O M T$. $\mathrm{G} \times \mathrm{E}$ represents the interaction between our measure of neuroplasticity and standardized birth weight. (ii) Demographic and family controls include race, sex, birth year (age), birth order, mother's education, father's education, and a score for family SES in 1957. (vi) Standard errors are clustered at the family level with $*, * *$, and $* * *$ representing significance at the 10,5 , and $1 \%$ significance level, respectively. 
Table C3. Baseline Interaction Controlling for Non-Linear Effects of Birth Weight: Cubic

\begin{tabular}{|c|c|c|c|}
\hline \multicolumn{4}{|c|}{ Dependent Variable: High School IQ } \\
\hline & $(1)$ & $(2)$ & $(3)$ \\
\hline Neuroplasticity Genes & $\begin{array}{c}0.4326 \\
(0.4355)\end{array}$ & $\begin{array}{c}0.3630 \\
(0.4340)\end{array}$ & $\begin{array}{l}-0.0384 \\
(0.7944)\end{array}$ \\
\hline Standardized Birth Weight & $\begin{array}{c}5.0404^{* * *} \\
(1.9320)\end{array}$ & $\begin{array}{c}5.3534^{* * *} \\
(1.8891)\end{array}$ & $\begin{array}{l}5.7081^{* *} \\
(2.6276)\end{array}$ \\
\hline Standardized Birth Weight Sqr. & $\begin{array}{l}-0.1390 \\
(0.2398)\end{array}$ & $\begin{array}{l}-0.0844 \\
(0.2563)\end{array}$ & $\begin{array}{l}-0.1225 \\
(0.3034)\end{array}$ \\
\hline Standardized Birth Weight Cubed & $\begin{array}{c}0.0205 \\
(0.0489)\end{array}$ & $\begin{array}{c}0.0143 \\
(0.0559)\end{array}$ & $\begin{array}{l}-0.0336 \\
(0.0647)\end{array}$ \\
\hline $\mathrm{G} \times \mathrm{E}$ & $\begin{array}{r}-0.8640^{* *} \\
(0.4285)\end{array}$ & $\begin{array}{c}-0.9377^{* *} \\
(0.4195)\end{array}$ & $\begin{array}{l}-0.9193 \\
(0.5709)\end{array}$ \\
\hline $\begin{array}{l}\text { Controls } \\
\text { Demographic and Family SES } \\
\text { Sibling Fixed Effects }\end{array}$ & $\begin{array}{l}\mathrm{Y} \\
\mathrm{N}\end{array}$ & $\begin{array}{l}\mathrm{Y} \\
\mathrm{N}\end{array}$ & $\begin{array}{l}\mathrm{Y} \\
\mathrm{Y}\end{array}$ \\
\hline $\begin{array}{l}\text { Estimation } \\
\text { Weighting by Prob. of Being in Sib Sample }\end{array}$ & $\mathrm{N}$ & $\mathrm{Y}$ & $\mathrm{N}$ \\
\hline $\begin{array}{l}N \\
\text { R Sqr. }\end{array}$ & $\begin{array}{c}938 \\
0.1369\end{array}$ & $\begin{array}{c}938 \\
0.1335\end{array}$ & $\begin{array}{c}938 \\
0.6982\end{array}$ \\
\hline
\end{tabular}

Notes: (i) Neuroplasticity Genes is the additive genetic risk score of plastic alleles for $A P O E, B D N F$, and $C O M T$. $\mathrm{G} \times \mathrm{E}$ represents the interaction between our measure of neuroplasticity and standardized birth weight. (ii) Demographic and family controls include race, sex, birth year (age), birth order, mother's education, father's education, and a score for family SES in 1957. (vi) Standard errors are clustered at the family level with *,**, and $* * *$ representing significance at the 10,5 , and $1 \%$ significance level, respectively. 


\section{Appendix D: Additional Tables for Labor Market Outcomes}

Table D1. Effect of Interaction on Productivity: Using an Indicator for Neuroplasticity

\begin{tabular}{|c|c|c|c|}
\hline \multicolumn{4}{|c|}{ Dependent Variable: ln Wage Rate in 1992} \\
\hline & $(1)$ & $(2)$ & $(3)$ \\
\hline \multicolumn{4}{|c|}{ Panel A: Main Effects } \\
\hline Neuroplasticity Genes & $\begin{array}{c}-0.2087^{* *} \\
(0.1000)\end{array}$ & $\begin{array}{c}-0.2181^{* *} \\
(0.1041)\end{array}$ & $\begin{array}{l}-0.2847 \\
(0.2507)\end{array}$ \\
\hline Standardized Birth Weight & $\begin{array}{c}0.0505 \\
(0.0476)\end{array}$ & $\begin{array}{c}0.0532 \\
(0.0479)\end{array}$ & $\begin{array}{c}0.1041 \\
(0.0795)\end{array}$ \\
\hline $\begin{array}{l}\text { Controls } \\
\text { Demographic and Family SES } \\
\text { Sibling Fixed Effects }\end{array}$ & $\begin{array}{l}\mathrm{Y} \\
\mathrm{N}\end{array}$ & $\begin{array}{l}\mathrm{Y} \\
\mathrm{N}\end{array}$ & $\begin{array}{l}\mathrm{Y} \\
\mathrm{Y}\end{array}$ \\
\hline $\begin{array}{l}\text { Estimation } \\
\text { Weighting by Prob. of Being in Sib Sample }\end{array}$ & $\mathrm{N}$ & $\mathrm{Y}$ & $\mathrm{N}$ \\
\hline $\begin{array}{l}N \\
\text { R Sqr. }\end{array}$ & $\begin{array}{c}820 \\
0.0954 \\
\end{array}$ & $\begin{array}{c}820 \\
0.0979 \\
\end{array}$ & $\begin{array}{c}820 \\
0.6025 \\
\end{array}$ \\
\hline \multicolumn{4}{|c|}{ Panel B: Gene-Environment Interaction } \\
\hline Neuroplasticity Genes & $\begin{array}{c}-0.2084^{* *} \\
(0.1001)\end{array}$ & $\begin{array}{c}-0.2172^{* *} \\
(0.1044)\end{array}$ & $\begin{array}{l}-0.2728 \\
(0.2459)\end{array}$ \\
\hline Standardized Birth Weight & $\begin{array}{c}0.1207^{*} \\
(0.0640)\end{array}$ & $\begin{array}{l}0.1182^{*} \\
(0.0628)\end{array}$ & $\begin{array}{c}0.3877^{* * *} \\
(0.1308)\end{array}$ \\
\hline $\mathrm{G} \times \mathrm{E}$ & $\begin{array}{l}-0.0979 \\
(0.0884)\end{array}$ & $\begin{array}{l}-0.0916 \\
(0.0879)\end{array}$ & $\begin{array}{c}-0.3918^{* * *} \\
(0.1359)\end{array}$ \\
\hline $\begin{array}{l}\text { Controls } \\
\text { Demographic and Family SES } \\
\text { Sibling Fixed Effects }\end{array}$ & $\begin{array}{l}\mathrm{Y} \\
\mathrm{N}\end{array}$ & $\begin{array}{l}\mathrm{Y} \\
\mathrm{N}\end{array}$ & $\begin{array}{l}\mathrm{Y} \\
\mathrm{Y}\end{array}$ \\
\hline $\begin{array}{l}\text { Estimation } \\
\text { Weighting by Prob. of Being in Sib Sample }\end{array}$ & $\mathrm{N}$ & Y & $\mathrm{N}$ \\
\hline $\begin{array}{l}N \\
\mathrm{R} \text { Sqr. }\end{array}$ & $\begin{array}{c}820 \\
0.0962\end{array}$ & $\begin{array}{c}820 \\
0.0986\end{array}$ & $\begin{array}{c}820 \\
0.6080\end{array}$ \\
\hline
\end{tabular}

Notes: This table recreates the estimates of Table 6 using alternate measure for neuroplasticity genes. Our base measure is the interaction between BDNF, COMT, and APOE, while the estimates in Table D1 use an indicator for having at least one plastic variant for each considered gene. 
Table D2. Effect of Interaction on Productivity: Using the Multiplicative Interaction of Plastic Alleles

\begin{tabular}{|c|c|c|c|}
\hline \multicolumn{4}{|c|}{ Dependent Variable: ln Wage Rate in 1992} \\
\hline & $(1)$ & $(2)$ & $(3)$ \\
\hline \multicolumn{4}{|c|}{ Panel A: Main Effects } \\
\hline Neuroplasticity Genes & $\begin{array}{l}-0.0141 \\
(0.0164)\end{array}$ & $\begin{array}{l}-0.0147 \\
(0.0164)\end{array}$ & $\begin{array}{l}-0.0187 \\
(0.0311)\end{array}$ \\
\hline Standardized Birth Weight & $\begin{array}{c}0.0501 \\
(0.0473)\end{array}$ & $\begin{array}{c}0.0526 \\
(0.0476)\end{array}$ & $\begin{array}{c}0.1008 \\
(0.0786)\end{array}$ \\
\hline $\begin{array}{l}\text { Controls } \\
\text { Demographic and Family SES } \\
\text { Sibling Fixed Effects }\end{array}$ & $\begin{array}{l}\mathrm{Y} \\
\mathrm{N}\end{array}$ & $\begin{array}{l}\mathrm{Y} \\
\mathrm{N}\end{array}$ & $\begin{array}{l}\mathrm{Y} \\
\mathrm{Y}\end{array}$ \\
\hline \multicolumn{4}{|l|}{ Estimation } \\
\hline $\begin{array}{l}N \\
\text { R Sqr. }\end{array}$ & $\begin{array}{c}820 \\
0.0919 \\
\end{array}$ & $\begin{array}{c}820 \\
0.0942 \\
\end{array}$ & $\begin{array}{c}820 \\
0.6009\end{array}$ \\
\hline \multicolumn{4}{|c|}{ Panel B: Gene-Environment Interaction } \\
\hline Neuroplasticity Genes & $\begin{array}{l}-0.0130 \\
(0.0165)\end{array}$ & $\begin{array}{l}-0.0136 \\
(0.0164)\end{array}$ & $\begin{array}{l}-0.0104 \\
(0.0311)\end{array}$ \\
\hline Standardized Birth Weight & $\begin{array}{l}0.1224^{* *} \\
(0.0526)\end{array}$ & $\begin{array}{l}0.1212^{* *} \\
(0.0525)\end{array}$ & $\begin{array}{c}0.3155^{* * *} \\
(0.1036)\end{array}$ \\
\hline $\mathrm{G} \times \mathrm{E}$ & $\begin{array}{r}-0.0241^{*} \\
(0.0129)\end{array}$ & $\begin{array}{r}-0.0231^{*} \\
(0.0127)\end{array}$ & $\begin{array}{c}-0.0664^{* * *} \\
(0.0209)\end{array}$ \\
\hline Controls & & & \\
\hline $\begin{array}{l}\text { Demographic and Family SES } \\
\text { Sibling Fixed Effects }\end{array}$ & $\begin{array}{l}\mathrm{Y} \\
\mathrm{N}\end{array}$ & $\begin{array}{l}\mathrm{Y} \\
\mathrm{N}\end{array}$ & $\begin{array}{l}\mathrm{Y} \\
\mathrm{Y}\end{array}$ \\
\hline $\begin{array}{l}\text { Estimation } \\
\text { Weighting by Prob. of Being in Sib Sample }\end{array}$ & $\mathrm{N}$ & $\mathrm{Y}$ & $\mathrm{N}$ \\
\hline $\begin{array}{l}N \\
\text { R Sqr. }\end{array}$ & $\begin{array}{c}820 \\
0.0936\end{array}$ & $\begin{array}{c}820 \\
0.0957\end{array}$ & $\begin{array}{c}820 \\
0.6069\end{array}$ \\
\hline
\end{tabular}

Notes: This table recreates the estimates of Table 6 using alternate measure for neuroplasticity genes. Our base measure is the additive risk score between BDNF, COMT, and APOE, while the estimates in Table D2 use the multiplicative interaction between BDNF, COMT, and APOE. 


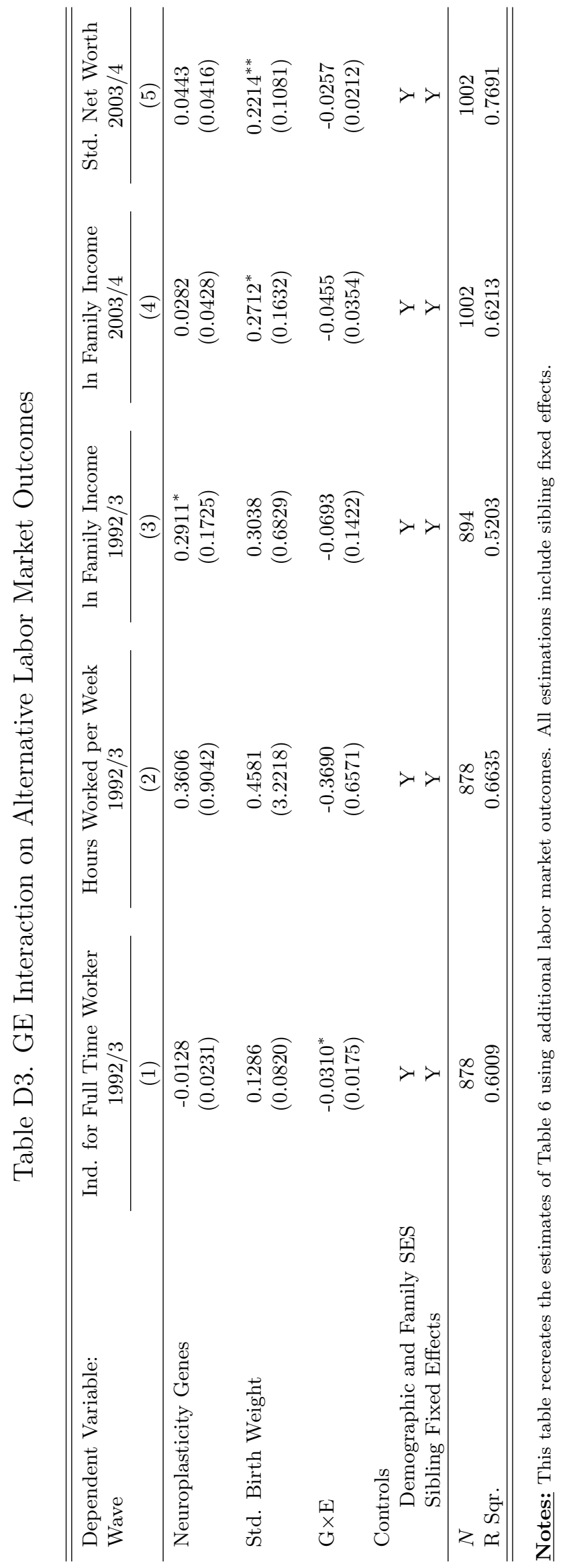




\section{Appendix E: Placebo Tests}

Table E1. Summary of t-statistics for All 3-way Genetic Combinations

\begin{tabular}{lccccc}
\hline \hline & $\mathrm{N}$ & Mean & Std. Dev. & Min & Max \\
\hline All 3-way combinations: & & & & & \\
$\quad$ t-statistic & 109,736 & -0.24 & 1.18 & -4.49 & 5.12 \\
Abs. t-stat. & 109,736 & 0.96 & 0.73 & 0.00 & 5.12 \\
Sample Size & 109,736 & 881.45 & 146.81 & 428 & 1004 \\
3-way combinations, excluding neuroplasticity SNPs: & & & & & \\
$\quad$ t-statistic & 95,284 & -0.28 & 1.17 & -4.39 & 5.12 \\
Abs. t-stat. & 95,284 & 0.96 & 0.73 & 0.00 & 5.12 \\
Sample Size & 95,284 & 878.08 & 149.23 & 428 & 1004 \\
\hline \hline
\end{tabular}




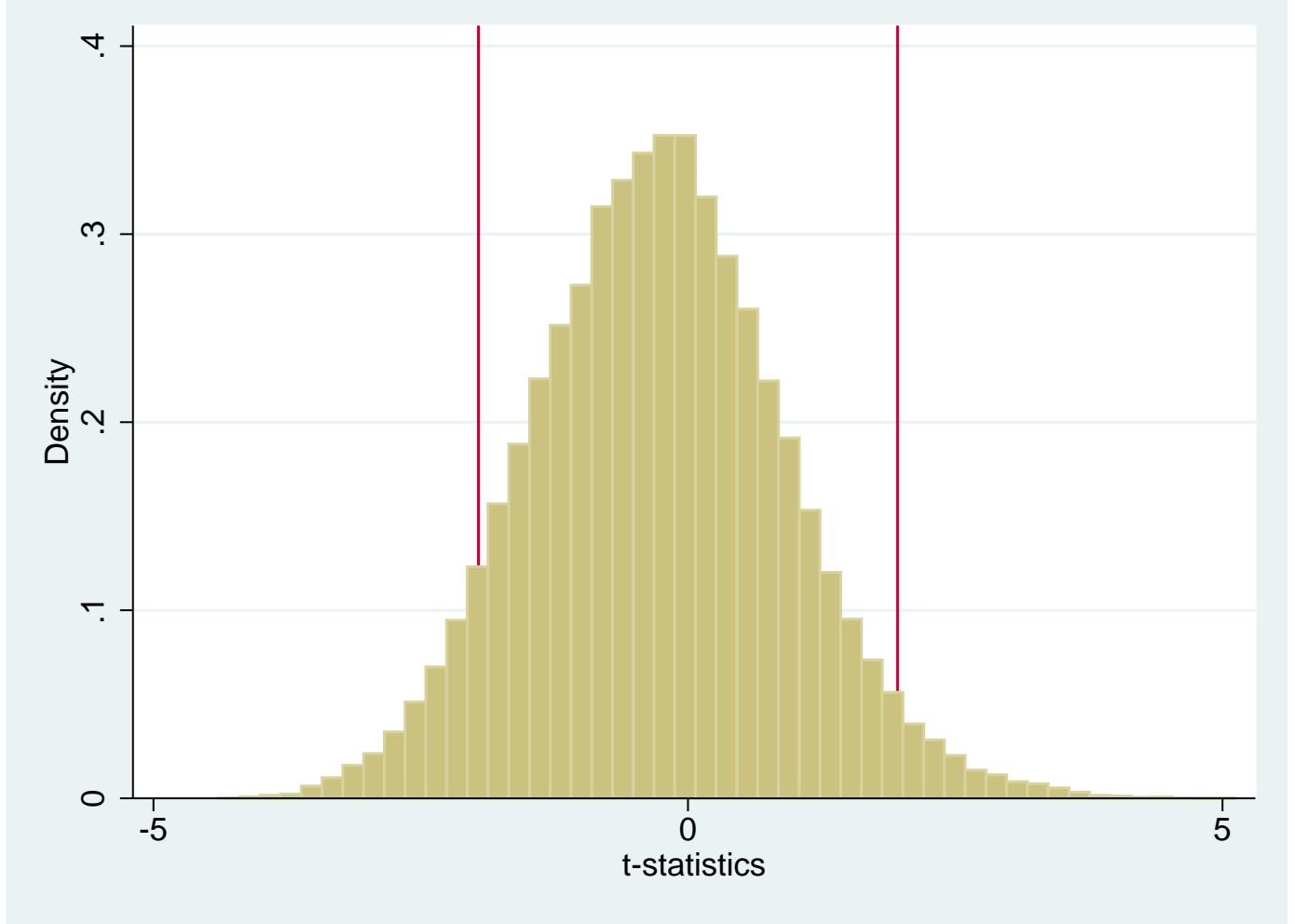

Figure E1. Significance of GxE for All 3-way SNP Combinations (excluding Neuroplasticity SNPs)

Notes: (i) This figure plots t-statistics for the coefficient of the interaction between birth weight and all possible 3-way genetic combinations (excluding neuroplasticity SNPs). After Bonferroni correction, no coefficient in the above figure remains statistically significant. 
Appendix F: Heterogeneity of Birth Weight

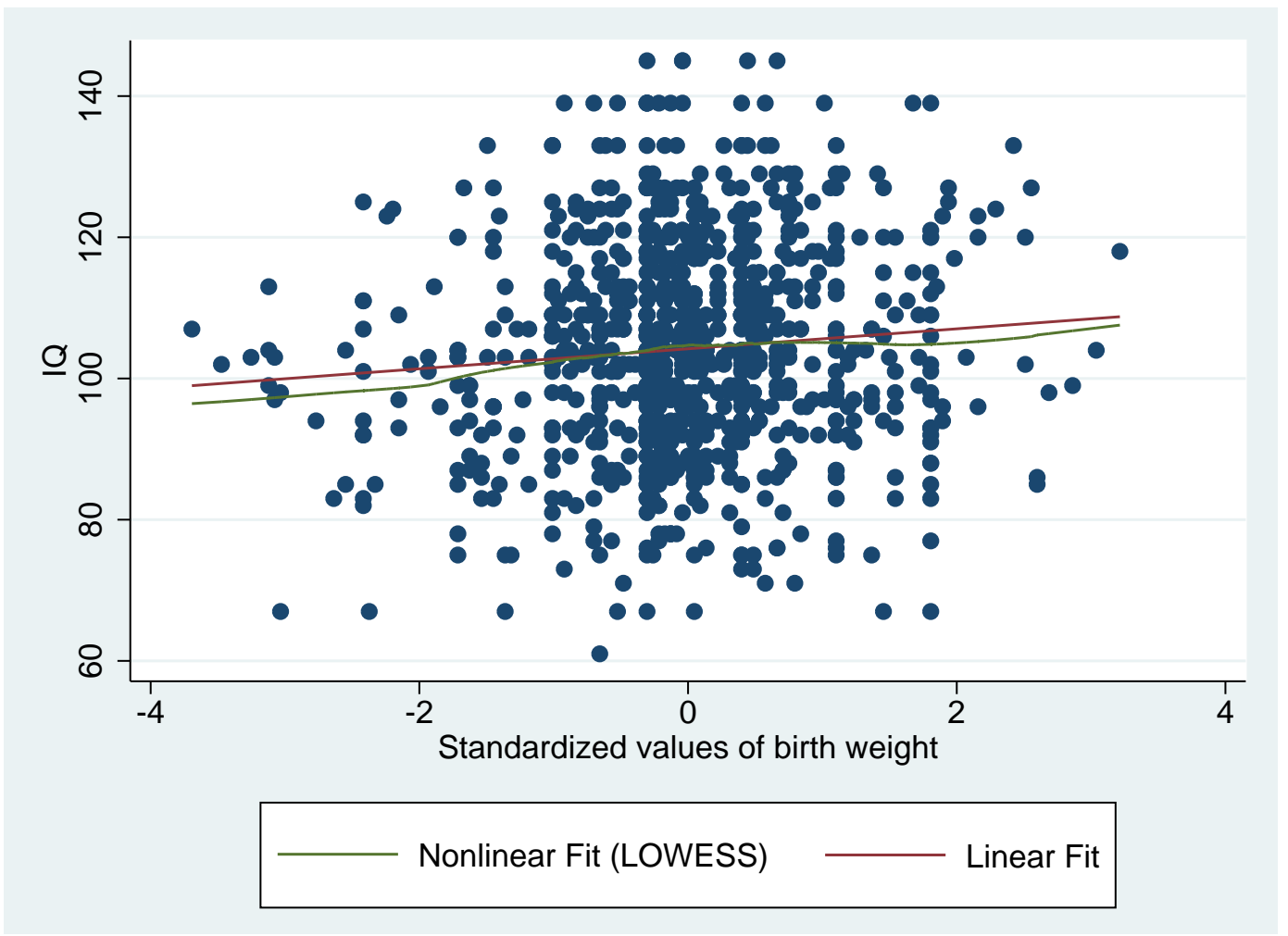

Figure F1. Linear vs. Nonlinear Fit of Birth Weight

Notes: This figure plots the linear association between birth weight and IQ as well as a non-linear, non-parametric association. Of note, the non-linear effect of birth weight is slightly lessened for low and high birth weight individuals. This finding supports our hypothesis of hetergoneity in birth weight. 
Table F1. Finite Mixture Model

\begin{tabular}{|c|c|c|}
\hline \multicolumn{3}{|c|}{ Dependent Variable: High School IQ } \\
\hline & $\begin{array}{l}\text { 2-component } \\
\text { (1) }\end{array}$ & $\begin{array}{l}\text { 3-component } \\
\text { (2) }\end{array}$ \\
\hline \multicolumn{3}{|l|}{ Component 1} \\
\hline Std. Birth Weight & $\begin{array}{c}1.3961^{* * *} \\
(0.4697)\end{array}$ & $\begin{array}{c}1.4319^{* * *} \\
(0.4726)\end{array}$ \\
\hline Birth Order & $\begin{array}{c}-1.1412^{* * *} \\
(0.4374)\end{array}$ & $\begin{array}{c}-1.0880^{* *} \\
(0.4427)\end{array}$ \\
\hline Birth Year & $\begin{array}{c}0.7766^{* * *} \\
(0.1243)\end{array}$ & $\begin{array}{c}0.7651^{* * *} \\
(0.1255)\end{array}$ \\
\hline Family SES & $\begin{array}{c}0.3460^{* * *} \\
(0.0490)\end{array}$ & $\begin{array}{c}0.3422^{* * *} \\
(0.0495)\end{array}$ \\
\hline \multicolumn{3}{|l|}{ Component 2} \\
\hline Std. Birth Weight & $\begin{array}{c}0.8315^{* * *} \\
(0.0471)\end{array}$ & $\begin{array}{c}0.8313^{* * *} \\
(0.0479)\end{array}$ \\
\hline Birth Order & $\begin{array}{c}-1.6836^{* * *} \\
(0.0282)\end{array}$ & $\begin{array}{c}-1.68355^{* * *} \\
(0.0281)\end{array}$ \\
\hline Birth Year & $\begin{array}{c}0.8127^{* * *} \\
(0.0056)\end{array}$ & $\begin{array}{c}0.8127^{* * *} \\
(0.0056)\end{array}$ \\
\hline Family SES & $\begin{array}{c}-0.8660^{* * *} \\
(0.0027)\end{array}$ & $\begin{array}{c}-0.8660^{* * *} \\
(0.0027)\end{array}$ \\
\hline \multicolumn{3}{|l|}{ Component 3} \\
\hline Std. Birth Weight & & $\begin{array}{c}1.4582^{* * *} \\
(0.1405)\end{array}$ \\
\hline Birth Order & & $\begin{array}{c}-8.4545^{* * *} \\
(0.1256)\end{array}$ \\
\hline Birth Year & & $\begin{array}{c}0.7823^{* * *} \\
(0.0222)\end{array}$ \\
\hline Family SES & & $\begin{array}{c}0.0212^{* * *} \\
(0.0034)\end{array}$ \\
\hline p-value, comp. $1=$ comp. 2 & 0.23 & - \\
\hline p-value, comp. $1=\operatorname{comp} .2=$ comp. 3 & - & 0.00 \\
\hline Obs. & 938 & 938 \\
\hline BIC & $7,654.51$ & $7,685.46$ \\
\hline
\end{tabular}

Notes: This table presents estimates from a finite mixture model. Given the relatively smaller, bur roughly similar, BIC, the 2-component model is preferred. For convergence of the model, a simpler set of controls is used. This set includes birth year, birth order, and family SES. Additionally, no weights are used in estimation. 


\section{Table F2. Neuroplasticity's Effect on Responsive to Birth Weight}

\begin{tabular}{lcc}
\hline \hline \multicolumn{2}{l}{ Dependent Variable: Indicator for being in "Responsive Sample" } \\
\hline & 2-component & 3-component \\
& $(1)$ & $(2)$ \\
\hline Neuroplasticity Genes & $-0.0121^{* *}$ & -0.0039 \\
& $(0.0058)$ & $(0.0069)$ \\
\hline Obs. & 938 & 938 \\
R Sqr. & 0.0119 & 0.0005 \\
\hline \hline
\end{tabular}

Notes: This table regresses the responsive group from FMM estimation in Table F1 on our measure of neuroplasticity. For the 2-component model, the size of the responsive group is 29 individuals, comprising roughly $3 \%$ of our sample. For the 3-component model, only 21 individuals, or $2.24 \%$ of our base sample, are found within the responsive sample. The negative (and significant in the 2-component model) coefficient on our measure of neuroplasticity implies more plastic individuals have smaller effects from birth weight on IQ, supporting our primary hypothesis. 


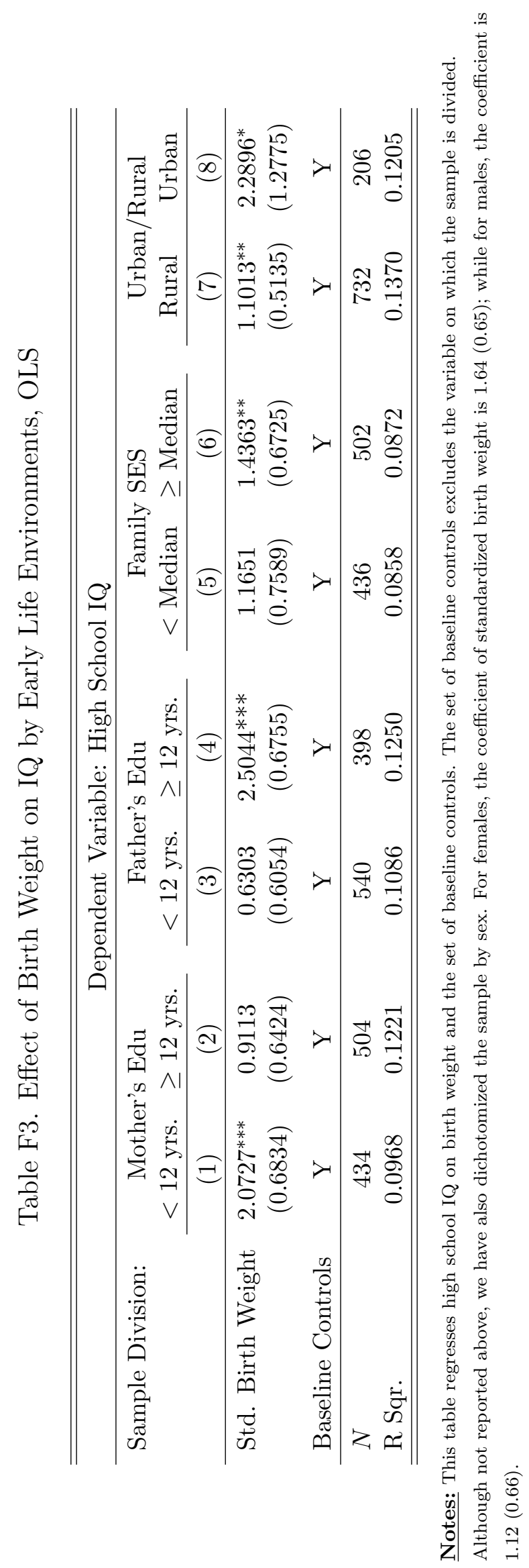




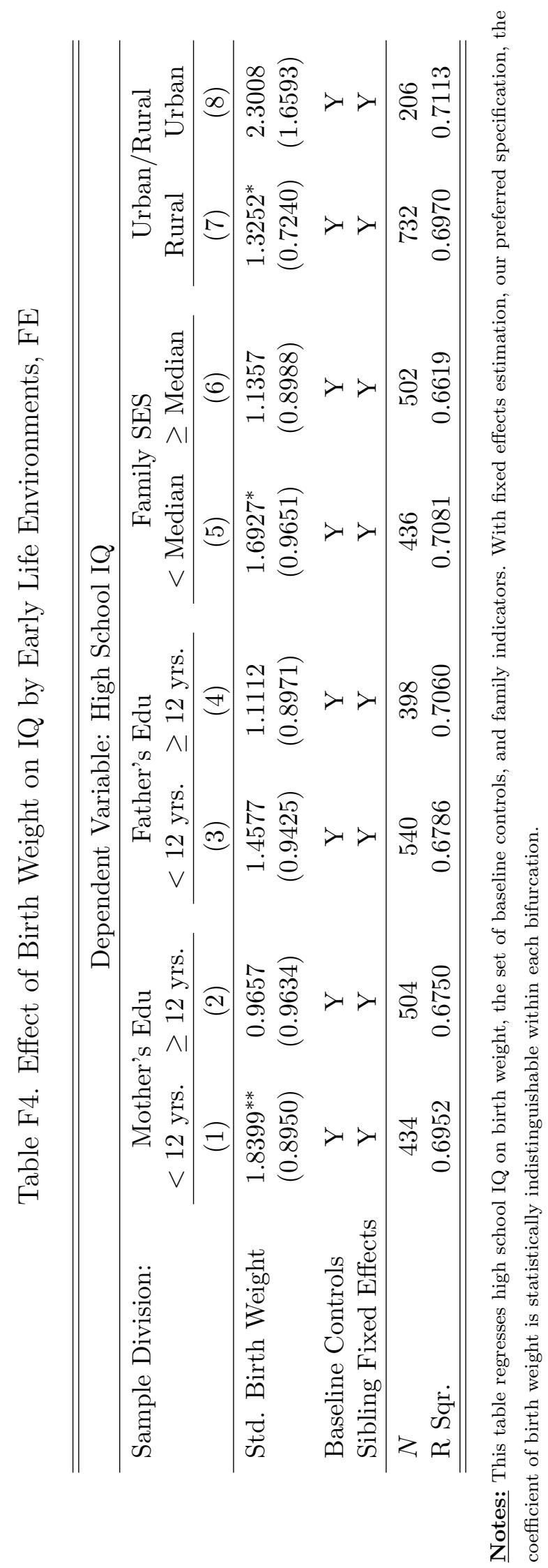

